\title{
Specifying the light-absorbing properties of aerosol particles in fresh snow samples, collected at the Environmental Research Station Schneefernerhaus (UFS), Zugspitze
}

\author{
Martin Schnaiter $^{1,2}$, Claudia Linke $^{1}$, Inas Ibrahim ${ }^{1}$, Alexei Kiselev ${ }^{1}$, Fritz Waitz $^{1}$, Thomas Leisner ${ }^{1}$, Stefan Norra $^{3}$, \\ and Till Rehm ${ }^{4}$ \\ ${ }^{1}$ Institute of Meteorology and Climate Research, Atmospheric Aerosol Research, KIT, Karlsruhe, Germany \\ ${ }^{2}$ schnaiTEC GmbH, Karlsruhe, Germany \\ ${ }^{3}$ Institute of Geography and Geoecology, KIT, Karlsruhe, Germany \\ ${ }^{4}$ Environmental Research Station Schneefernerhaus (UFS), Zugspitze, Germany
}

Correspondence: Martin Schnaiter (martin.schnaiter@kit.edu) and Claudia Linke (claudia.linke@kit.edu)

Received: 18 December 2018 - Discussion started: 23 January 2019

Revised: 2 August 2019 - Accepted: 8 August 2019 - Published: 28 August 2019

\begin{abstract}
Atmospheric aerosol particles like mineral dust, volcanic ash and combustion particles can reduce Earth's snow and ice albedo considerably even by very small amounts of deposited particle mass. In this study, a new laboratory method is applied to measure the spectral light absorption coefficient of airborne particles that are released from fresh snow samples by an efficient nebulizing system. Threewavelength photoacoustic absorption spectroscopy is combined with refractory black carbon (BC) mass analysis to determine the snow mass-specific and BC mass-specific absorption cross sections. Fullerene soot in water suspensions are used for the characterization of the method and for the determination of the mass-specific absorption cross section of this $\mathrm{BC}$ reference material. The analysis of 31 snow samples collected after fresh snowfall events at a high-altitude Alpine research station reveals a significant discrepancy between the measured snow mass-specific absorption cross section and the cross section that is expected from the $\mathrm{BC}$ mass data, indicating that non-BC light-absorbing particles are present in the snow. Mineral dust and brown carbon $(\mathrm{BrC})$ are identified as possible candidates for the non-BC particle mass based on the wavelength dependence of the measured absorption. For one sample this result is confirmed by environmental scanning electron microscopy and by single-particle fluorescence measurements, which both indicate a high fraction of biogenic and organic particle mass in the sample.
\end{abstract}

\section{Introduction}

Light-absorbing atmospheric particles like black carbon $(\mathrm{BC})$, brown carbon $(\mathrm{BrC})$, mineral dust or volcanic ash are eventually removed from the atmosphere by dry and wet deposition. Light-absorbing particles that are deposited onto snowpacks result in a darkening of the white surface, which increases the absorption of solar radiation. Because pure snow is the most reflective natural surface on Earth, the presence of small amounts of absorptive impurities changes the optical properties of snow, resulting in a considerable reduction of the snow albedo (Warren, 1982; Warren and Wiscombe, 1980). In cold, fine-grained snow the observed BC amounts of $\leq 100 \mathrm{ng} \mathrm{g}^{-1}$ can reduce the spectral albedo at visible wavelengths by up to $2 \%$, while in melting snow, these reductions can even increase to $6 \%$ (Warren and Wiscombe, 1985). Although these numbers seem to be small, they result in a significant impact on the radiation budget via the snow albedo effect (Clarke and Noone, 1985; Flanner et al., 2007), which also includes secondary effects like rapid snow transformation (e.g. changes in the snow grain size) and the retreat of snow and ice covers in a warming climate. The IPCC reported a global annual mean radiative forcing for anthropogenic BC in snow and ice of $+0.04 \mathrm{~W} \mathrm{~m}^{-2}$ with an uncertainty range of 0.02 to $0.09 \mathrm{~W} \mathrm{~m}^{-2}$ (Boucher et al., 2013). A considerably higher radiative forcing estimate for BC in snow is given in Bond et al. (2013). In their estimate they calculated an effective BC in snow forcing that includes 
feedback mechanisms, like rapid adjustments of the snowpack and the climate response to the snow and ice albedo changes, resulting in a best forcing estimate of $+0.13 \mathrm{~W} \mathrm{~m}^{-2}$ with an uncertainty of 0.04 to $0.33 \mathrm{~W} \mathrm{~m}^{-2}$.

For a reliable assessment of the radiative forcing by lightabsorbing impurities in snow and ice, the response of the snow albedo to the presence of light-absorbing particles has to be understood from a physical basis. This is not a trivial task as the spectral albedo of snow depends not only on the mass mixing ratio of the absorbing particles in the snowpack, but also on the chemical composition, the microphysical properties and the spectral absorption properties of the particles in addition to the snow grain size distribution and the spatial variations of these parameters (Flanner et al., 2007). While the mass mixing ratio of $B C$ in snow (and also that of mineral dust and organic carbon) has been the subject of many recent studies (e.g. Kaspari et al., 2014; Schmale et al., 2017; Zhang et al., 2018), their microphysical and spectral optical properties are still poorly understood. A few studies exist on the microphysical (Dong et al., 2018; Zhang et al., 2017) and optical properties (Dal Farra et al., 2018; Doherty et al., 2010; Kaspari et al., 2014; Schwarz et al., 2013), but these are too sparse to give a conclusive understanding. Further, the optical properties of light-absorbing impurities are often indirectly addressed by either applying simplified optical particle models (e.g. Schwarz et al., 2013) or by using mass-specific absorption cross sections (MACs) determined for atmospheric particles (e.g. Dong et al., 2018; Zhou et al., 2017). There is a need for more studies that address the question on the microphysical nature and the optical properties of particles in snow and ice. In a large-area study on lightabsorbing impurities in Arctic snow, Doherty et al. (2010) applied the integrating sandwich with integrating sphere technique (ISSW; Grenfell et al., 2011) to measure the snow mass-specific spectral absorption cross section, $\sigma_{\mathrm{abs}}$, on filter samples. The ISSW is an improved version of the original integrating plate (IP) filter method that was used in the pioneering work of Clarke and Noone (1985) to determine the BC in the Arctic snowpack. Although the ISSW method measures $\sigma_{\mathrm{abs}}$, they used a fixed MAC for BC and assumed fixed absorption Angström exponents for $\mathrm{BC}$ and non- $\mathrm{BC}$ to calculate the $\mathrm{BC}$ mass mixing ratios and the fraction of non$\mathrm{BC}$ particles in the snow, respectively. However, large biases have been revealed in laboratory tests of the ISSW when non-BC-absorbing and purely light-scattering particles are co-deposited on the filter (Schwarz et al., 2012). This indicates a significant cross-sensitivity of the ISSW-determined $\sigma_{\text {abs }}$ to particle light scattering.

In the present study we used a different approach to measure $\sigma_{\mathrm{abs}}$ by applying three-wavelength photoacoustic spectroscopy to re-aerosolized snow samples. Photoacoustic aerosol spectroscopy is not prone to light-scattering artefacts and therefore gives reliable results even in the presence of light-scattering impurities. In a pilot study for this approach freshly fallen snow was collected at the German Alpine re- search station Schneefernerhaus over a period of 6 months in the winter of 2016/2017. Particulate impurities in the samples were re-aerosolized in the laboratory and were concurrently measured by a Single Particle Soot Photometer (SP2) as well as by a homebuilt three-wavelength photoacoustic spectrometer (PAAS-3 $\lambda$ ) to determine $\sigma_{\text {abs }}$ and the BC MAC of the snow impurities. Suspensions of fullerene soot in water were prepared as a standard for melted snow and were used to characterize the nebulizer efficiency and to determine the PAAS- $3 \lambda$ detection sensitivity. From these measurements the MAC of the fullerene soot standard was deduced and compared with the MAC of the snow samples.

Sample preparation, test particle properties and the experimental setup are given in Sect. 2. Section 3 describes the characterization of the nebulizer at different operational settings and gives the efficiency of the nebulizer in terms of particle number and mass concentrations. The MAC of the fullerene soot standard is presented in Sect. 4. Measurement results of the snow samples are discussed in Sect. 5, followed by conclusions given in Sect. 6 .

\section{Experiment}

\subsection{Snow samples}

The snow samples used in this study originate from the Environmental Research Station Schneefernerhaus (UFS). The station is located at a latitude of $47^{\circ} 25^{\prime} 00^{\prime \prime} \mathrm{N}$, a longitude of $10^{\circ} 58^{\prime} 46^{\prime \prime} \mathrm{E}$ and an altitude of $2650 \mathrm{~m}$ a.s.l. During winter the UFS is usually situated in the free troposphere with low boundary layer influence (Gilge et al., 2010), but can be occasionally affected by long-range transported Saharan dust plumes (Flentje et al., 2015) or in rare events by Transatlantic aerosol transport (Birmili et al., 2010). The station is located within a skiing and hiking resort and is therefore sporadically affected by local anthropogenic emissions during daytime, e.g. from snow groomers during the skiing season. Yuan et al. (2019) report multiple short-term atmospheric CO events and higher atmospheric NO peaks during the weekdays (mostly around 09:00 LT) at the station. Disregarding these local pollution events at the station, the multi-annual median $\mathrm{BC}$ mass concentration is $0.1 \mu \mathrm{g} \mathrm{m}^{-3}$, while winter months have a considerably lower BC concentration (Sun et al., 2019).

Snow samples were collected from December 2016 to May 2017. Precipitation, maximum and minimum temperatures, sunshine duration and wind speed data were provided by the German Meteorological Service (DWD). Equivalent BC mass concentrations from Multi-Angle Absorption Photometer (MAAP, ThermoFisher Scientific, USA) measurements and mineral dust loads were provided by the German Federal Environment Agency (UBA) and the DWD, respectively. The snow samples were taken either during or just after snowfall events by scraping off only the top few centime- 


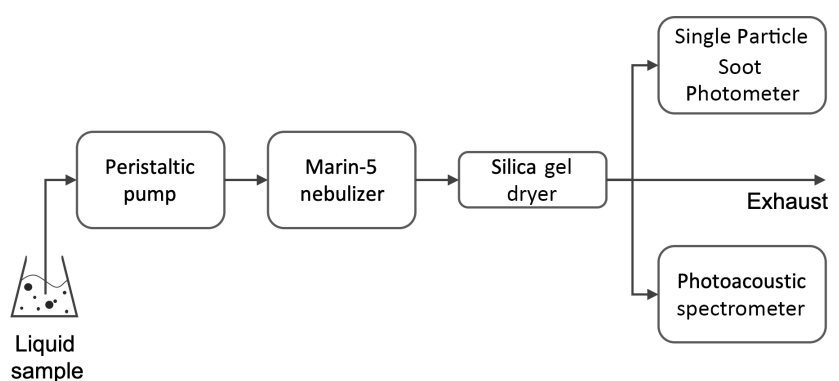

Figure 1. Schematic of the instrumental setup used in the present study.

tres of the snowpack to avoid sampling older snow. A metallic hand shovel is used to sample the snow from an area of about $30 \times 30 \mathrm{~cm}$ into a zipper-sealed polyethylene household plastic bag with a volume of $1 \mathrm{~L}$ (Toppits, Germany). In this way, snow from the beginning of the snowfall event could be missed, but most of the time the events were accompanied by heavy wind, which made it impossible to fully sample the fresh snow layer. After collection the samples were stored at the UFS in a freezer at $-18^{\circ} \mathrm{C}$ until they were transported under frozen conditions to the laboratory at the Karlsruhe Institute of Technology (KIT). Over the course of the study period 33 samples were taken at the UFS.

Right before the analysis, which is described in the following sections, approximately $30 \mathrm{~mL}$ of snow is removed from the plastic bag and is put in a glass beaker for further treatment. This subsample is then melted by sonication in an ultrasonic bath (EMAG Technologies, Germany) at room temperature for about $5 \mathrm{~min}$. Sonication during the melting process should help to avoid particle adhesion to the wall of the glass beaker. Aqueous snow/ice sample sonication prior to the analysis is recommended by several groups (e.g. Kaspari et al., 2011; Wendl et al., 2014), although with inconclusive results of the obtained improvements. The melted samples were never refrozen for later analysis as this can result in a significant particle mass loss of up to $60 \%$ (Wendl et al., 2014).

\subsection{Setup of instruments}

The experimental setup consisted of a Marin-5 Enhanced Nebulizer System (Teledyne CETAC Technologies, USA), a homebuilt three-wavelength photoacoustic aerosol absorption spectrometer (PAAS-3 $\lambda$, Linke et al., 2016) and an SP2 (Droplet Measurement Technologies, USA), as shown in Fig. 1. The liquid samples are fed by a peristaltic pump (ISM795, ISMATEC, Wertheim, Germany) equipped with Tygon tubing (ID $0.76 \mathrm{~mm}$, E-LFL, Fisher Scientific, USA) into a concentric pneumatic glass nebulizer ("MicroMist 500 " with a critical orifice of $500 \mu \mathrm{m}$ ), which is positioned inside of the Marin-5 nebulizer (see Fig. S1 in the Supplement for a schematic of the nebulizer). The glass nebulizer consists of a capillary that directs the liquid sample to the nebulizer tip where a concentric sheath flow of pressurized synthetic air disperses the supplied liquid sample into a spray (Katich et al., 2017). The optimum specified liquid sample flow rate of the glass nebulizer, which is set on the peristaltic pump, is $R_{\mathrm{pp}}=0.5 \mathrm{~mL} \mathrm{~min}^{-1}$. The generated spray is released into the nebulizing chamber of the Marin-5 nebulizer with the maximum specified gas flow rate of $R_{\mathrm{neb}}=1.1 \mathrm{~L} \mathrm{~min}^{-1}$. The spray enters the heated section of the chamber where the water is evaporated, forming a moist aerosol of residual particles. This aerosol comprises refractory aerosol particles and residues from soluble material that were contained in the liquid sample. Subsequently, the aerosol passes the cooled section of the chamber where excess water is eliminated from the sample flow by condensation to the chamber walls, so that the bulk of water vapour in the moist aerosol is drained before the particles leave the nebulizer. The aerosol that exits the nebulizer is then directed through a homebuilt silica gel dryer to reduce the relative humidity of the aerosol flow below $20 \%$ RH. Finally, sample flows for the SP2 and the PAAS- $3 \lambda$ are taken from the aerosol flow, which is otherwise exhausted to the ambient air.

The SP2 was used to determine the refractory black carbon (BC) mass concentration $c_{\mathrm{BC}}^{\mathrm{SP} 2}$ of the $\mathrm{BC}$ suspension standards and the snow samples. The instrument is typically operated with a sample flow rate of $0.12 \mathrm{~L} \mathrm{~min}^{-1}$. For singleparticle mass determination the two incandescence channels of the instrument are calibrated with fullerene soot particles (Alfa Aesar, no. 40971, lot no. F12S011), which are size-selected by a differential mobility analyser (DMA) in the range of 100 to $450 \mathrm{~nm}$, corresponding to single-particle refractory $\mathrm{BC}$ masses of about 0.5 to $30 \mathrm{fg}$. Note that this "fullerene soot" material actually contains only less than $10 \%$ by mass of fullerene molecules (Laborde et al., 2012a). The gains of the two incandescence channels of the SP2 are adjusted in a way that they cover a combined volumeequivalent size range from 60 to $560 \mathrm{~nm}$ (Laborde et al., 2012b). To quantify the number efficiency of the nebulizer, number concentrations of non-absorbing PSL particles are determined from the SP2 single-particle scattering data. For analysis of the SP2 data, the software toolkit developed and provided by Martin Gysel from the Paul Scherrer Institute, Switzerland, is used (Gysel et al., 2011).

The PAAS- $3 \lambda$ is a single-cavity three-wavelength photoacoustic aerosol absorption spectrometer that has been designed and built at the KIT. The instrument is currently marketed by schnaiTEC GmbH. The following briefly describes the basic measurement concept, explained in detail by Linke et al. (2016). Using the spectrometer to measure the absorption coefficient $b_{\text {abs }}$ of aerosols, a controlled sample flow of $0.85 \mathrm{~L} \mathrm{~min}^{-1}$ is led through the acoustic resonator of the instrument. This open-ended cylindrical cavity has a diameter of $6.5 \mathrm{~mm}$ and a length of $49 \mathrm{~mm}$ resulting in a fundamental acoustic resonance frequency of about $3200 \mathrm{~Hz}$. Acoustic buffers of $24.5 \mathrm{~mm}$ length and $78 \mathrm{~mm}$ diameter are attached 
to both ends of the cavity to filter acoustic disturbances that may exist in the frequency range of the resonator. Possible disturbances comprise noise generated in the flow system as well as ambient sound. The photoacoustic cell composed of the acoustic resonator and the buffers has a total volume of $236 \mathrm{~cm}^{3}$. The PAAS-3 3 system was developed to determine the absorption coefficients at three wavelengths across the visible spectral range. Three lasers (Dragonlaser, Changchun, China), modulated at the resonance frequency of the acoustic cavity, are used in this study. The lasers have emitting wavelengths of 405,532 , and $658 \mathrm{~nm}$ and generate modulated emission power of 100,150 , and $130 \mathrm{~mW}$, respectively. The modulation frequency has a duty cycle of $50 \%$ and is tuned to the resonance frequency of the acoustic cavity on a daily basis. The detection limit $(2 \sigma)$ of this setup was derived from Allan deviation analysis of long-term background signal measurements similar to the analysis presented in Fischer and Smith (2018). The Allan deviation plot for the three PAAS-3 $\lambda$ wavelengths is shown in Fig. S2. According to this analysis, the PAAS- $3 \lambda$ instrument has a $2 \sigma$ detection limit in the range of 1.2 to $2.1 \mathrm{Mm}^{-1}$ for all three wavelengths and for a typical averaging time of $60 \mathrm{~s}$.

\subsection{Supplementary measurements}

To further examine the nature of the particulate components that are deposited in the snow samples, ion chromatography (IC) and an inductive coupled plasma mass spectrometry (ICP-MS) analysis were exemplarily conducted for the snow sample from 10 March 2017, mainly to clarify the concentration of higher ions which might be present in the snow. Additionally, the aerosol released from this snow sample was fed to a Waveband Integrated Bioaerosol Sensor (University of Hertfordshire, UK, WIBS4) to get information on the biogenic particle fraction. For these additional analyses, re-aerosolized airborne particles were sampled downstream from the nebulizing system behind the dryer by substituting the PAAS-3 $\lambda$ and the SP2 (see Fig. 1). A Nuclepore ${ }^{\text {TM }}$ filter with pore sizes of $0.2 \mu \mathrm{m}$ was taken for microscopic analysis using an Environmental Scanning Electron Microscope (ESEM; Quattro S, ThermoFisher Scientific, USA) combined with EDX microanalysis (EDAX, Octane Elite Super). This analysis further characterizes the different particle types found mainly in the larger particle size range (larger than $\sim 500 \mathrm{~nm}$ ) of this sample.

\subsection{PSL particles}

The characterization of the particle number efficiency of the nebulizer and the daily performance control was performed with monodisperse polystyrene latex (PSL) particles (Postnova Analytics GmbH, Landsberg am Lech, Germany) with nominal diameters of $240 \pm 5$ and $304 \pm 5 \mathrm{~nm}$. The particle number concentration within these suspensions is about $3 \times 10^{8} \mathrm{~mL}^{-1}$. A diluted PSL standard suspension sample was prepared daily by pipetting $1 \mathrm{~mL}$ suspension into a $100 \mathrm{~mL}$ graduated flask filled with ultrapure water.

\subsection{Fullerene soot standards}

Suspensions of known fullerene soot mass concentrations were prepared to determine the particle mass efficiency $\varepsilon_{\text {neb }}$ of the nebulizer. The material has been widely used to calibrate SP2 instruments (including the present study) as it gives a sensitivity that is similar to diesel soot (Laborde et al., 2012a). A stock suspension of fullerene soot particles (Alfa Aesar, USA; stock no. 40971, lot no. F12S011) suspended in ultrapure water was stored in a $250 \mathrm{~mL}$ graduated glass bottle with a polypropylene cap (Simax, Czech Republic) for several days to allow larger particles to settle out of the suspension. From this stock suspension the supernatant suspension was taken to (a) determine the fullerene soot mass concentration gravimetrically and to (b) prepare diluted fullerene soot standard suspensions for daily particle mass efficiency control of the nebulizer.

For the gravimetric analysis of the settled stock suspension two empty quartz fibre filters (MK360, Ahlstrom Munksjö, Finland) were dried overnight at $50^{\circ} \mathrm{C}$, stored in a dehydrator for $2 \mathrm{~h}$ and weighed with a microbalance (M3P, Sartorius, Germany). Then $30 \mathrm{~mL}$ of the supernatant suspension was extracted from the stock fullerene soot suspension and was dropped on both quartz filters. The filters were then temperature treated the same way as the empty filters before and being weighed again. From the gravimetric fullerene soot mass, the mass concentration of the stock suspension was determined to be $5.8 \pm 2.6 \mu \mathrm{g} \mathrm{mL}^{-1}$ (mean $\pm 1 \sigma ; N=2$ ). Four fullerene soot standard suspensions for the determination of the mass efficiency $\varepsilon_{\text {neb }}$ of the nebulizer were prepared on each measurement day from the stock suspension. This was performed in two dilution steps, resulting in samples of fullerene soot suspended in ultrapure water with nominal mass concentrations of $c_{\mathrm{FS}}=11.5 \pm 2.5,23 \pm 7.3,34.5 \pm 6.3$ and $46 \pm 7.7 \mathrm{ng} \mathrm{mL}^{-1}$. Note that the given uncertainty range is based on the analysis of the SP2 mass measurements acquired during the characterization of the Marin-5 nebulizing efficiency (Sect. 3) and does not reflect possible systematic biases in the above gravimetric analysis of the stock suspension and the subsequent dilution process.

\section{Characterization of the nebulizer}

Particles suspended in liquid samples are not completely dispersed during the nebulizing process in the Marin-5 nebulizer; instead, the particles are partially lost in the drain water of the instrument. To characterize the Marin-5 dispersion efficiency the nebulizer settings were varied while measuring the particle output by a Condensation Particle Counter (CPC) (Model 3775, TSI Inc., USA). In this characterization the operation recommendations given by Katich et 
al. (2017) for applying the Marin-5 in snow sample analyses were mainly adopted. However, a minimum gas flow rate of $R_{\text {neb }}=0.97 \mathrm{~L} \mathrm{~min}^{-1}$ is necessary in the present study to simultaneously operate the SP2 and the PAAS- $3 \lambda$ downstream from the Marin-5. Also, the relative humidity of the Marin-5 output flow is an important property here as reliable photoacoustic measurements of aerosol systems require a relative humidity below $\sim 30 \%$ (Langridge et al., 2013). The particle output (in terms of particle number and particle mass) and the relative humidity depend on the $R_{\mathrm{pp}}$ and $R_{\text {neb flow rates }}$ and the temperatures of the heated and cooled sections of the nebulizing chamber. As a starting point of the Marin-5 characterization the nebulizer parameters were set to heating and cooling temperatures of 120 and $5^{\circ} \mathrm{C}$, respectively, the maximum specified input air flow rate of $R_{\text {neb }}=1.1 \mathrm{~L} \mathrm{~min}^{-1}$, and a liquid sample flow rate of $R_{\mathrm{pp}}=0.08 \mathrm{~mL} \mathrm{~min}^{-1}$. Each parameter, except $R_{\text {neb }}$, was varied while keeping the others constant. The results of this characterization are presented in the Supplement. Based on these findings, the liquid sample flow rate was set to $R_{\mathrm{pp}}=0.32 \mathrm{~mL} \mathrm{~min}^{-1}$ in the fullerene soot and snow sample analyses in order to generate a sufficient absorption signal in the PAAS- $3 \lambda$ while the aerosol can still be dried to a relative humidity below $30 \%$. The nebulizer temperatures were set to 120 and $5^{\circ} \mathrm{C}$ for the heated and cooled sections, respectively.

With the above settings and the setup shown in Fig. 1, the mass nebulizing efficiency $\varepsilon_{\mathrm{neb}}=c_{\mathrm{BC}}^{\mathrm{SP} 2} / c_{\mathrm{FS}} \cdot R_{\mathrm{neb}} / R_{\mathrm{pp}}$ of the Marin-5 nebulizer was derived from measurements using the fullerene soot standard suspensions described in Sect. 2.4. In Fig. S4 the detected SP2 mass concentrations $c_{\mathrm{BC}}^{\mathrm{SP} 2}$ are shown for the four fullerene soot standards which were daily prepared. The mass nebulizing efficiency was determined to be $39 \%$ from these measurements, which is in very good agreement with the findings of Katich et al. (2017) for similar settings.

Figure 2 shows the average mass size distributions of the four fullerene soot suspension standards used in the characterization of the Marin-5 mass nebulizing efficiency $\varepsilon_{\text {neb }}$ shown in Fig. S4. Each size distribution is an average over eight individual suspensions that were prepared on a daily basis. The measured mass size distribution of each of the 32 individual suspensions was fitted by a lognormal function to get the mass-equivalent median diameter (MMD), the width of the distribution (i.e. geometric standard deviation $\sigma_{\mathrm{g}}$ ), as well as the integrated mass concentration, $c_{\mathrm{BC}}^{\mathrm{SP} 2}$. Note that the integrated mass concentration $c_{\mathrm{BC}}^{\mathrm{SP} 2}$ from the lognormal fit was used in determination of $\varepsilon_{\text {neb }}$ and the fullerene soot mass absorption cross sections, MAC ${ }_{\mathrm{FS}}$, in Sect. 4. This is necessary as the summed particle mass from the SP2 measurement alone ignores particles with sizes larger than $560 \mathrm{~nm}$, which represent a mass fraction of about $10 \%$ (see Fig. 2). The suspensions show very stable MMDs of $227 \pm 3.7,226 \pm 1.7,228.5 \pm 2.5$, and $229 \pm 1.7 \mathrm{~nm}$ and $\sigma_{\mathrm{g}}$ of $1.57 \pm 0.018,1.56 \pm 0.024,1.57 \pm 0.017$, and $1.57 \pm 0.016$ for the $11.5,23,34.5$, and $46 \mathrm{ng} \mathrm{mL}^{-1}$ suspensions, respectively,

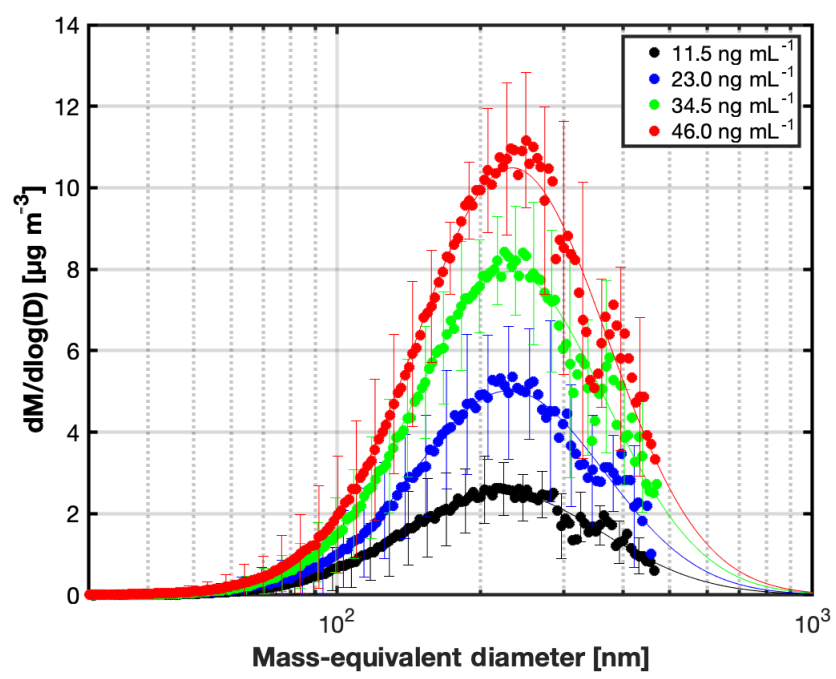

Figure 2. Particle mass size distributions of the fullerene soot suspensions used to characterize the Marin-5 nebulizer. The measurements were conducted with the SP2, which has an upper size limit of $560 \mathrm{~nm}$ in the present study. Results from lognormal fits are represented by the thin lines.

with a MMD of $228 \pm 3 \mathrm{~nm}$ and a $\sigma_{\mathrm{g}}$ of $1.57 \pm 0.018$ when averaging over all 32 samples (Table 1 ).

\section{Specific mass absorption cross sections $\left(\mathrm{MAC}_{\mathrm{FS}}\right)$ of fullerene soot}

Simultaneously to the BC mass concentration measurements with the SP2, the absorption coefficients $b_{\text {abs }}$ of the fullerene soot suspensions were measured for the three PAAS- $3 \lambda$ wavelengths. Both measurements together enable the determination of the mass-specific absorption cross section $\mathrm{MAC}_{\mathrm{FS}}=b_{\mathrm{abs}} / c_{\mathrm{BC}}^{\mathrm{SP} 2}$ of airborne fullerene soot at 405,532 , and $658 \mathrm{~nm}$. In Fig. 3, the absorption coefficients $b_{\mathrm{abs}}$ are plotted against the SP2-derived BC mass concentrations $c_{\mathrm{BC}}^{\mathrm{SP} 2}$ of the fullerene soot suspension standards. Linear regression fits of the data result in $\mathrm{MAC}_{\mathrm{FS}}$ values of $10.5 \pm 3.2$, $9.5 \pm 2.2$, and $8.6 \pm 3.3 \mathrm{~m}^{2} \mathrm{~g}^{-1}$ for 405,532 , and $658 \mathrm{~nm}$, respectively. The $\mathrm{MAC}_{\mathrm{FS}}$ at $532 \mathrm{~nm}$ is comparable to the value of $8.84 \mathrm{~m}^{2} \mathrm{~g}^{-1}$ given by Schwarz et al. (2012) for fullerene soot (lot no. F12S011) deduced from ISSW measurements, but is significantly higher than the $6.1 \pm 0.4 \mathrm{~m}^{2} \mathrm{~g}^{-1}$ (mean \pm $2 \sigma$ ) measured recently by photoacoustic absorption spectroscopy for size-selected fullerene soot particles by Zangmeister et al. (2018). The latter authors used a combination of a DMA and an aerosol particle mass analyser (APM) to select fullerene soot particles within a narrow mass range from aerosol generated by an atomizer. Their $\mathrm{MAC}_{\mathrm{FS}}$ of $6.1 \mathrm{~m}^{2} \mathrm{~g}^{-1}$, which is given for a wavelength of $550 \mathrm{~nm}$, a mobility-equivalent diameter of $350 \mathrm{~nm}$, and a particle mass of $16.6 \times 10^{-15} \mathrm{~g}$, corresponds to a volume-equivalent diameter of $264 \mathrm{~nm}$ using a density of $1.72 \mathrm{~g} \mathrm{~cm}^{-3}$ of fullerene 
Table 1. Overview of the optical and BC mass properties measured for the fullerene soot suspension standards as well as the fresh snow samples.

\begin{tabular}{|c|c|c|}
\hline & Fullerene soot & UFS snow samples \\
\hline $\begin{array}{l}\text { MAC }(405 \mathrm{~nm})\left(\mathrm{m}^{2} \mathrm{~g}^{-1}\right)(\text { mean } \pm 1 \sigma) \\
(5 \text { th-95th percentile range })\end{array}$ & $\begin{array}{r}10.5 \pm 3.2 \\
7.6-14.0\end{array}$ & $\begin{array}{r}21.1 \pm 7.9 \\
13.4,33.1\end{array}$ \\
\hline $\begin{array}{l}\operatorname{MAC}(532 \mathrm{~nm})\left(\mathrm{m}^{2} \mathrm{~g}^{-1}\right)(\text { mean } \pm 1 \sigma) \\
(5 \text { th-95th percentile range })\end{array}$ & $\begin{array}{r}9.5 \pm 2.2 \\
7.7-16.0\end{array}$ & $\begin{array}{r}18.2 \pm 7.2 \\
10.9,27.2\end{array}$ \\
\hline $\begin{array}{l}\operatorname{MAC}(658 \mathrm{~nm})\left(\mathrm{m}^{2} \mathrm{~g}^{-1}\right)(\text { mean } \pm 1 \sigma) \\
(5 \text { th-95th percentile range })\end{array}$ & $\begin{array}{r}8.6 \pm 3.3 \\
5.7,10.9\end{array}$ & $\begin{array}{r}11.9 \pm 4.6 \\
8.1,20.2\end{array}$ \\
\hline $\begin{array}{l}\text { AAE }(405-658 \mathrm{~nm}) \\
\text { AAE }(405-532 \mathrm{~nm}) \\
\text { AAE }(532-658 \mathrm{~nm}) \\
(\text { mean } \pm 1 \sigma)\end{array}$ & $\begin{array}{l}0.46 \pm 0.07 \\
0.35 \pm 0.08 \\
0.60 \pm 0.12\end{array}$ & $\begin{array}{l}1.20 \pm 0.85 \\
0.49 \pm 1.00 \\
2.10 \pm 2.24\end{array}$ \\
\hline $\begin{array}{l}\text { Mass median diameter }(\mathrm{nm})(\text { mean } \pm 1 \sigma) \\
(5 \text { th-95th percentile range })\end{array}$ & $\begin{array}{r}228 \pm 3 \\
223.5-233\end{array}$ & $\begin{array}{r}207.5 \pm 42.1 \\
146.2-290.4\end{array}$ \\
\hline $\begin{array}{l}1 \sigma \text { distribution width (mean } \pm c \text { ) } \\
(5 \text { th-95th percentile range) }\end{array}$ & $\begin{array}{r}1.57 \pm 0.018 \\
1.54-1.6\end{array}$ & $\begin{array}{r}1.83 \pm 0.13 \\
1.64-2.06\end{array}$ \\
\hline $\begin{array}{l}\sigma_{\text {abs }}(405 \mathrm{~nm})\left(10^{-8} \mathrm{~m}^{2} \mathrm{~mL}^{-1}\right) \\
\text { (median, 5th-95th percentile range) }\end{array}$ & & $9.9,4.3-37.9$ \\
\hline $\begin{array}{l}\sigma_{\text {abs }}(532 \mathrm{~nm})\left(10^{-8} \mathrm{~m}^{2} \mathrm{~mL}^{-1}\right) \\
\text { (median, 5th-95th percentile range) }\end{array}$ & & $8.4,2.9-34.2$ \\
\hline $\begin{array}{l}\sigma_{\text {abs }}(658 \mathrm{~nm})\left(10^{-8} \mathrm{~m}^{2} \mathrm{~mL}^{-1}\right) \\
\text { (median, 5th-95th percentile range) }\end{array}$ & & $5.9,1.9-21.5$ \\
\hline $\begin{array}{l}c_{\mathrm{BC}}^{\mathrm{SP} 2}\left(\mathrm{ng} \mathrm{mL} \mathrm{L}^{-1}\right) \\
\text { (median, 5th-95th percentile range) }\end{array}$ & & $5.0,1.7-20.4$ \\
\hline $\begin{array}{l}c_{\mathrm{BC}}^{\text {equiv }}(532 \mathrm{~nm})\left(\mathrm{ng} \mathrm{mL}^{-1}\right) \\
\text { (median, 5th-95th percentile range) }\end{array}$ & & $8.9,3.1-36.1$ \\
\hline
\end{tabular}

soot (Kondo et al., 2011). Although this diameter is not very different from the MMD of $228 \mathrm{~nm}$ of the fullerene soot suspensions used here, part of the observed discrepancy can be attributed to the different sizes as the MAC is strongly dependent on the particle diameter for particles larger than about $200 \mathrm{~nm}$ (e.g. Moosmüller et al., 2009). To be comparable, we measured the $\mathrm{MAC}_{\mathrm{FS}}$ of size-selected fullerene soot particles in a separate study by adding a DMA behind the Marin-5 in the setup shown in Fig. 1. A MAC $\mathrm{FS}_{\text {of }} 8.6 \mathrm{~m}^{2} \mathrm{~g}^{-1}$ was measured for the mobility-equivalent diameter of $350 \mathrm{~nm}$, which is still $\sim 40 \%$ larger than the $\mathrm{MAC}_{\mathrm{FS}}$ given by Zangmeister et al. (2018) for the same diameter. However, they used an APM to measure the BC mass, while an SP2 was used here to deduce the refractory $\mathrm{BC}$ mass. According to Laborde et al. (2012a), the fullerene soot product shows a variability between batches which results in an SP2 calibration uncertainty of up to $15 \%$ (actually only two batches were compared: lot no. F12S011 and lot no. L18U002). They explained the differences in the SP2 response (i.e. the calibration curves) by a substantial non-refractory coating in the case of the
L18U002 batch that could be identified by thermodenuding the samples. Assuming that lot no. W08A039 used in Zangmeister et al. (2018) has a similar coating, this would increase the APM mass measurement by about $15 \%$ compared to the SP2-derived BC mass of lot no. F12S011 used in the present study. This in turn would increase the MAC $\mathrm{FS}_{\mathrm{F}}$ from $6.1 \mathrm{~m}^{2} \mathrm{~g}^{-1}$ reported by Zangmeister et al. (2018) to about $7 \mathrm{~m}^{2} \mathrm{~g}^{-1}$ when using only the refractory BC mass fraction in the calculation of the $\mathrm{MAC}_{\mathrm{FS}}$. This assumption reduces the discrepancy between the two $\mathrm{MAC}_{\mathrm{FS}}$ values to $35 \%$, which is within the uncertainty range of $\pm 2.2 \mathrm{~m}^{2} \mathrm{~g}^{-1}$ for our $532 \mathrm{~nm}$ value. It is further conceivable that different batches of the fullerene soot material have different electronic band structure (i.e. refractive index) and/or fractal aggregate structures that both change the absorption cross section of the particles at a constant particle mass (e.g. Liu et al., 2019; Zangmeister et al., 2018). Figure 4 shows an electron micrograph of a typical fullerene soot aggregate sampled from the dry aerosol output of the Marin-5 nebulizer. The fullerene soot particles do not have a simple fractal aggre- 
gate structure, but are rather complex-structured with polydisperse monomer sizes, monomer nonsphericity (irregularity), necking and overlapping, which all have a significant impact on the optical particle properties (including the absorption cross section) compared to the idealized fractal aggregate (Teng et al., 2019). Since these microphysical details of the soot particles are very sensitive to the actual formation and subsequent treatment conditions (Gorelik et al., 2002), it is conclusive that the $\mathrm{MAC}_{\mathrm{FS}}$ has an even higher variability between different fullerene soot batches compared to what is expected from the SP2 mass sensitivity only.

The wavelength dependence of the aerosol light absorption, expressed by the so-called absorption Angström exponent (AAE), was determined to be $0.46 \pm 0.07$ for the used fullerene soot suspensions by analysing the $b_{\text {abs }}$ data for the 405 and $658 \mathrm{~nm}$ wavelengths (Table 1). This AAE is close to the $\sim 0.6$ reported by Baumgardner et al. (2012) for fullerene soot derived from multiwavelength PSAP and aethalometer measurements, and it is within the range of the $0.54 \pm 0.06$ determined by Zhou et al. (2017) from ISSW spectrometer measurements on fullerene soot filter samples in the 450 to $750 \mathrm{~nm}$ spectral range. However, it is significantly lower than the $0.92 \pm 0.05$ given by Zangmeister et al. (2018) for fullerene soot lot no. W08A039. Here again, we have to take into account that Zangmeister et al. (2018) analysed sizesegregated absorption spectra, and their AAE is given for a mobility-equivalent diameter of $350 \mathrm{~nm}$. Analysing our sizesegregated measurements gives an AAE of $0.82 \pm 0.02$ for the same mobility-equivalent diameter, which is closer to, but smaller than, the Zangmeister et al. value. This further supports the above assumption that there is a difference in the chemical as well as physical (including optical) properties between different batches of the fullerene soot product.

In conjunction with the $b_{\mathrm{abs}}$ detection limit of $2.1 \mathrm{Mm}^{-1}$ given in Sect. 2.2 for the PAAS-3 $\lambda$ and the mass nebulizing efficiency $\varepsilon_{\text {neb }}$ of the Marin-5 nebulizer given in Sect. 3, the $\mathrm{MAC}_{\mathrm{FS}}$ analysis shown in Fig. 3 can be used to assess the detection limit of the PAAS- $3 \lambda$ in terms of the BC mass mixing ratio in the snow. A conservative estimate that also accounts for the uncertainties in the preparation and quantification of the fullerene soot suspension standards gives a lower $\mathrm{BC}$ mass mixing ratio of $4 \mathrm{ng} \mathrm{mL}^{-1}$ that can be optically detected by the PAAS- $3 \lambda$ using the setup shown in Fig. 1. Therefore, the method presented here should be suitable for analysing the visible light absorption of $\mathrm{BC}$ snow impurities for continental as well as for the most of the Arctic areas (e.g. Table 1 in Warren, 2019).

\section{Results and discussion of the snow sample measurements}

The instrumental setup was used to measure a set of 33 snow samples from the UFS in the same way as the fullerene soot standards before. The results of two samples were dis-

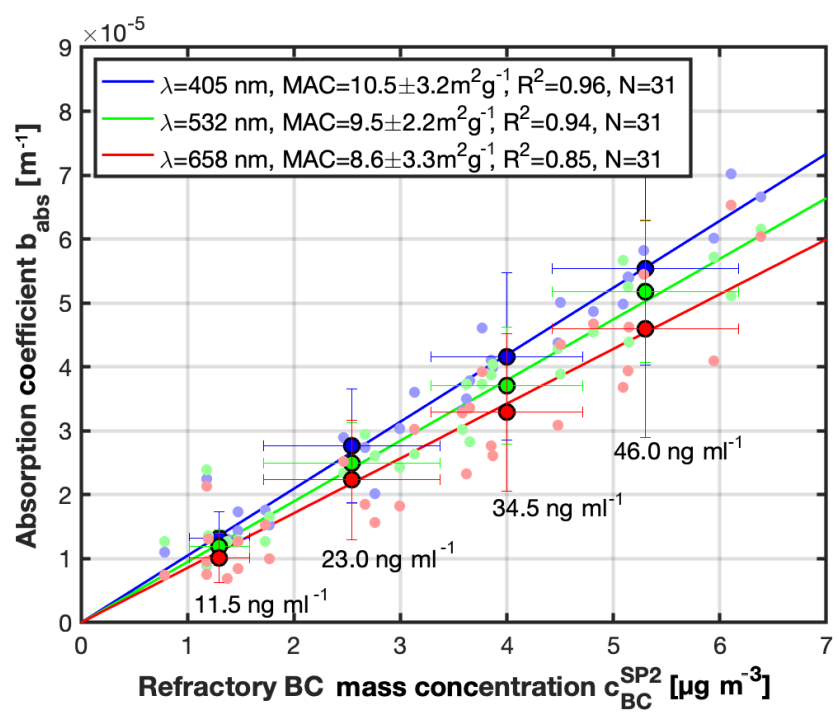

Figure 3. Determination of the mass-specific absorption cross section (MAC) of re-aerosolized fullerene soot suspension standards at 405,532 , and $658 \mathrm{~nm}$. The MAC values are given in the legend and are derived from concurrent measurements of the absorption coefficient, $b_{\mathrm{abs}}$, using the photoacoustic aerosol absorption spectrometer PAAS- $3 \lambda$ and the refractory $\mathrm{BC}$ mass concentration, $c_{\mathrm{BC}}^{\mathrm{SP}}$, using the SP2. A linear regression without intercept was applied to the measurement data (solid lines).

carded from data presented here because they show inexplicably high BC mass concentrations and absorption coefficients (factors of 5 to 10 outside the 95th percentile of the other samples). This indicates a possible contamination from local sources. The measured refractory BC mass concentrations of the aerosolized snow samples were corrected for the Marin-5 nebulizing efficiency to determine the $\mathrm{BC}$ mass concentrations per $\mathrm{mL}$ volume of melted snow. This $\mathrm{BC}$ concentration is shown in Fig. 5c in conjunction with the eBC mass concentration of ambient air that is routinely measured by UBA using a MAAP. A selection of meteorological data is also presented in Fig. 5 to highlight the variations in ambient temperature, sunshine duration, snow precipitation and snow height over the period the snow samples were collected at the UFS station. Although there is no clear correlation between the fresh snow samples and ambient air eBC mass concentration, the enhanced air eBC mass concentration observed at the end of March and beginning of April might have resulted in additional deposition of BC particles in the snow surface that is reflected - with a time lag of several days - in the measured snow refractory $\mathrm{BC}$ mass mixing ratio. Interestingly, this period of higher air eBC concentration is distinguished by a little precipitation activity, long sunshine periods and frequent daily maximum temperatures above the melting point which resulted in frequent thaw-freeze cycles and, consequently, a gradual decrease in the snow height by 30 to $40 \mathrm{~cm}$. All in all, the enhanced air eBC concentration in conjunction with the meteorological conditions would favour 


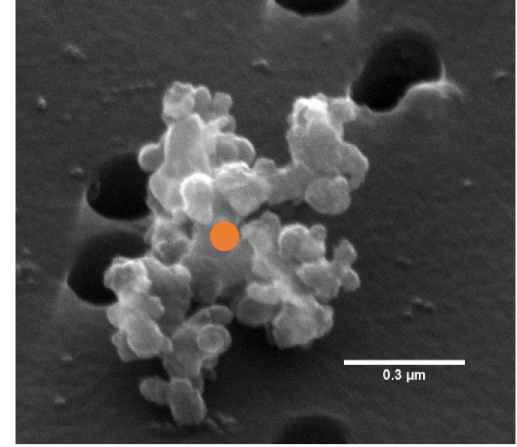

(a)

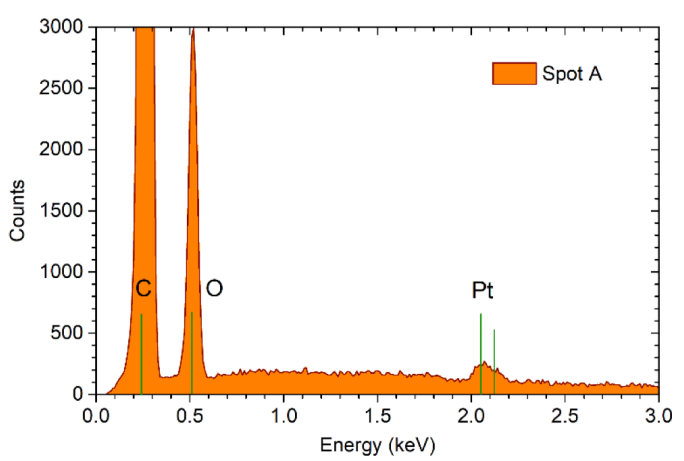

(b)

Figure 4. Morphology and composition of a fullerene soot particle extracted from the Marin-5 nebulizer output on a Nuclepore ${ }^{\mathrm{TM}}$ filter. (a) The SEM secondary electron image. (b) EDX spectrum obtained from spot A on the particle (marked by the orange circle in the SEM image). The spectrum shows a pure carbonaceous signature with only the $\mathrm{C}$ and $\mathrm{O}$ peaks. Sample coating is responsible for the Pt peak at $2.08 \mathrm{keV}$.
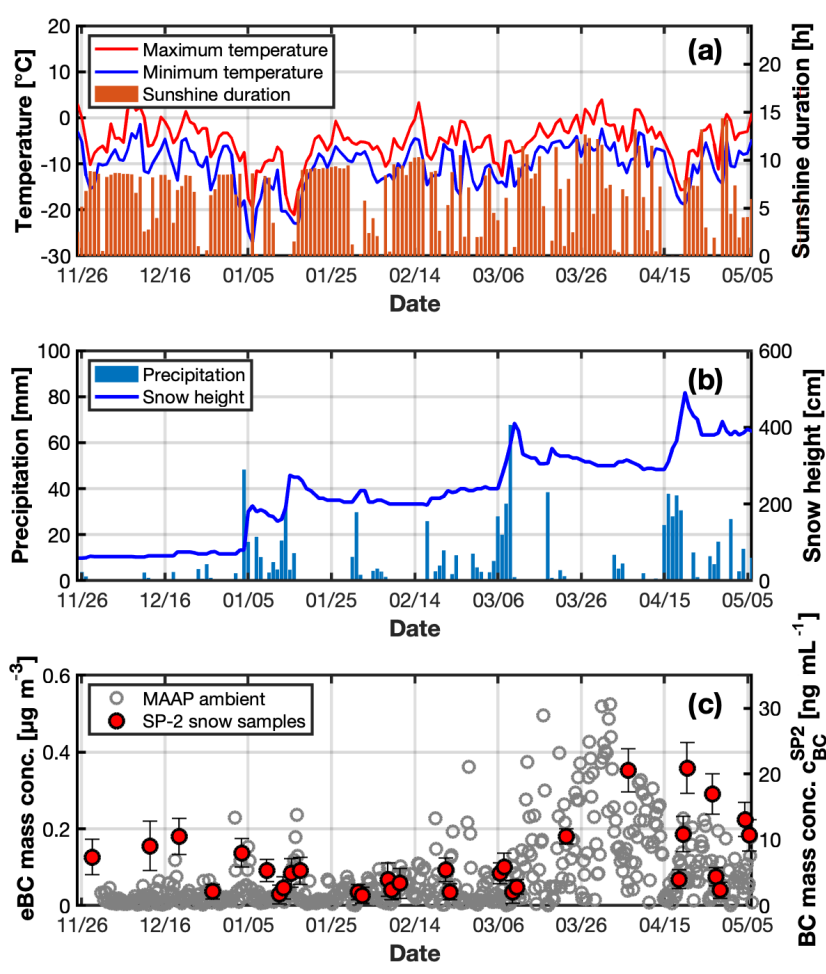

Figure 5. Overview of the meteorological and ambient BC conditions during the period the snow samples were collected at UFS. The data in (a) to (b) are on a daily basis. The atmospheric equivalent black carbon (eBC) mass concentrations shown in panel (c) represent $30 \mathrm{~min}$ averages of the MAAP measurements. Note that the refractory black carbon mass concentrations, $c_{\mathrm{BC}}^{\mathrm{SP} 2}$, deduced from the SP2 measurements of the re-aerosolized snow samples are compared in panel (c) with the atmospheric eBC mass concentration. See text for details concerning data providers, sampling, and measurement methods. enhanced BC mass concentrations in the fresh snow samples collected after precipitation events within this period or shortly after. Figure 6 shows corresponding mass size distributions of the refractory BC concentrations shown in Fig. 5c averaged over the periods of November to January, February and March, as well as April and May. For comparison purposes, the average size distributions are normalized by the corresponding total mass concentration $M_{\text {total }}$, which was deduced from a lognormal fit. The SP2-derived refractory BC mass size distribution only includes particles up to a massequivalent diameter of $560 \mathrm{~nm}$, which means that larger BC particles are not recorded by the SP2. However, the average BC mass size distributions have distinct mode maxima at the MMDs of 227, 194, and $222 \mathrm{~nm}$ for the NovemberJanuary, February-March, and April-May periods, respectively. This indicates no strong seasonality in the snow BC mass size distribution even in the April-May period where the $\mathrm{BC}$ mass concentration in the snow was significantly enhanced (Fig. 5c). This further implies that fresh snow was indeed sampled which has not experienced thaw-freeze cycles severe enough to induce an agglomeration of the $\mathrm{BC}$ particles in the top snow layer. This conclusion is further supported by comparing the average $\mathrm{BC}$ mass size distributions of our snow samples with the BC mass size distribution of a fresh snow sample collected after a long-lasting snowfall event at Ny-Ålesund, Svalbard, Norway, by Sinha et al. (2018) and with the averaged BC size distribution from five snow samples collected after three snowfall events in the semi-rural and rural surroundings of Denver, CO, USA, by Schwarz et al. (2013). Our average fresh snow sample size distributions peak at similar MMD between 194 and $227 \mathrm{~nm}$ compared to the $223 \pm 28 \mathrm{~nm}$ of the Sinha et al. study and the $\sim 220 \mathrm{~nm}$ of the Schwarz et al. study. In addition, our size distributions indicate a non-lognormal "shoulder" at the upper size limit of the SP2 measurement that is in a very good agreement with the Schwarz et al. (2013) samples where the refractory BC 


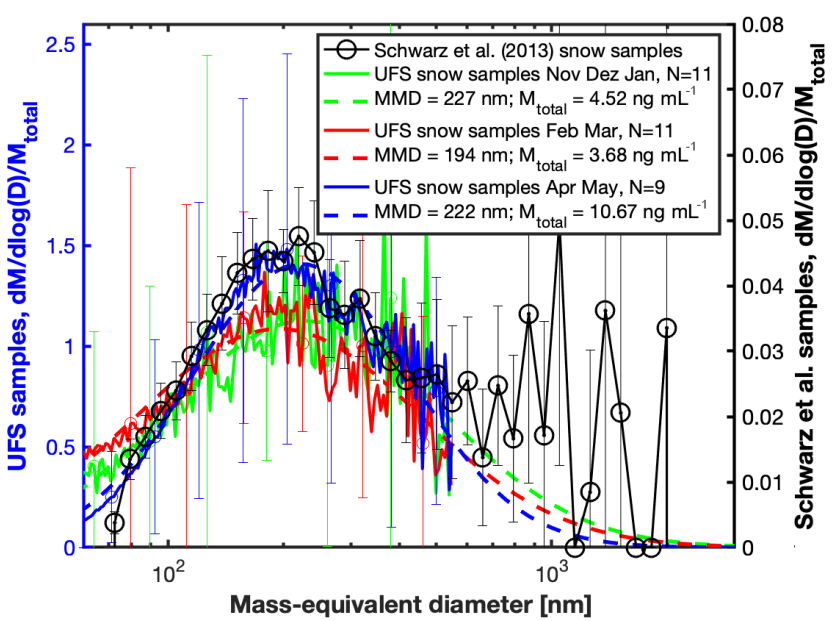

Figure 6. BC mass size distributions of the snow samples deduced from the SP2 measurements. The size distributions are averaged over the three periods November-December-January (green), February-March (red), and April-May (blue) and are normalized by the total mass $\left(M_{\text {total }}\right)$. Lognormal fits are represented by the dashed lines. Fit results in terms of mass median diameter (MMD) and integrated mass $\left(M_{\text {total }}\right)$ are given in the legend. An averaged size distribution for fresh snow samples published by Schwarz et al. (2013) is shown for comparison (black line and open circles).

mass size distributions were measured by an SP2 with modified detector gains up to $2 \mu \mathrm{m}$ (see Fig. 6). As pointed out by Schwarz et al. (2013), such snow BC mass size distributions reflect the typical atmospheric $\mathrm{BC}$ mass size distribution that is observed at remote locations altered by agglomeration and size-selection processes during snow formation in the atmosphere. The good agreement between the mass size distributions of our snow samples and the average distribution of the Schwarz et al. (2013) samples allows us to estimate the refractory $\mathrm{BC}$ mass that is contained in the large particle size shoulder outside our measurement range. According to Schwarz et al. (2013) a fraction of $28 \%$ of the total BC mass can be attributed to particles with mass-equivalent diameters larger than $600 \mathrm{~nm}$. A mass correction factor of 1.39 is therefore applied to the SP2-derived refractory BC snow concentrations in the following analysis.

For the assessment of the albedo effect of particulate impurities in snow surfaces the spectral absorption that is contained in the snow has to be quantified. As already mentioned in the introduction, this is usually achieved by quantifying the mass mixing ratio of light-absorbing particles in the snow and applying a mass-specific absorption cross section to that particle mass resulting in a total absorption cross section per snow mass $\sigma_{\text {abs }}$ (given in $\mathrm{m}^{2} \mathrm{~mL}^{-1}$ ). With the measurement setup given in Fig. 1, this quantity is directly assessable. To deduce $\sigma_{\mathrm{abs}}$ the measured absorption coefficient $b_{\mathrm{abs}}\left(\mathrm{m}^{-1}\right)$ of the aerosol released from the snow sample is converted by the equation

$\sigma_{\mathrm{abs}}=10^{-3} \cdot b_{\mathrm{abs}} \cdot R_{\mathrm{neb}} / R_{\mathrm{pp}} \cdot \varepsilon_{\mathrm{neb}}^{-1}$,

with $R_{\text {neb }}$ and $R_{\mathrm{pp}}$ being the air and liquid sample flow rates of the nebulizer, and $\varepsilon_{\text {neb }}$ the nebulizing efficiency. A unit conversion factor of $10^{-3}$ is necessary because $b_{\mathrm{abs}}$ is given as $\left(\mathrm{m}^{2} \mathrm{~m}^{-3}\right)$, while $R_{\text {neb }}$ is given as $\left(\mathrm{L} \mathrm{min}^{-1}\right) . \sigma_{\mathrm{abs}}$ values are calculated for the 31 UFS snow samples using Eq. (1) and are plotted in Fig. 7 as a function of the corresponding refractory BC mass concentrations $c_{\mathrm{BC}}^{\mathrm{SP} 2}$, which were corrected for the missing larger particle mass in accordance with the discussion above. This results in a strong correlation between the snow mass-specific absorption cross section $\sigma_{\mathrm{abs}}$ and the refractory $\mathrm{BC}$ mass concentration of the snow samples which defines the mass absorption cross section, MAC, of the snow particles. In Table 1, the MAC values of the snow samples are compared with those determined for the fullerene soot suspension standards. It is clear from Table 1 that the MAC of the snow particles is significantly larger than the MAC of the fullerene soot by wavelength-dependent factors of 2.0, 1.9, and 1.4 for 405,532 , and $658 \mathrm{~nm}$, respectively. This observation suggests that (i) the $\mathrm{BC}$ particles in the snow are thickly coated with transparent or low-absorbing material that results in a real absorption amplification of the internally mixed particles by the so-called lensing effect (e.g. Schnaiter et al., 2005), and/or (ii) part of the absorbing aerosol mass in these samples might be mineral dust or brown carbon that is codeposited with the $\mathrm{BC}$ mass and has a significant and strong wavelength-dependent mass absorption cross section in the visible spectral region (Schnaiter et al., 2006; Wagner et al., 2012). Both explanations are conclusive for atmospheric aerosol observed at a remote location like the UFS. Although the wavelength dependence of the observed absorption "enhancement" suggests an insignificant impact from thickly coated BC particles - as this should show a larger absorption amplification in the red compared to the blue spectral range (Schnaiter et al., 2005) - the lensing effect is strongly dependent on the actual coating thickness, the coating material, the composite particle size and the geometrical particle configuration (Kahnert et al., 2012; You et al., 2016). Further, the mean AAE of the snow samples for the spectral ranges from 405 to 658 and 532 to $658 \mathrm{~nm}$ is $1.20 \pm 0.85$ and $2.10 \pm 2.24$, respectively, which is significantly larger but more varying than $0.46 \pm 0.07$ and $0.60 \pm 0.12$ deduced for the fullerene soot suspensions for the same spectral ranges (Table 1). This suggests that it is more likely that the $\mathrm{BC}$ particles in the snow are accompanied by non-BC aerosol particles in varying amounts that induce additional absorption predominantly in the blue and green part of the visible spectrum.

Doherty et al. (2010) analysed spectroscopic measurements of Arctic snow samples using the ISSW photometer to deduce the equivalent $\mathrm{BC}$ mass concentration $c_{\mathrm{BC}}^{\text {equiv }}$, i.e. the amount of $\mathrm{BC}$ that would need to be present in the snow to account for the measured absorption. With the concurrent PAAS-3 $\lambda$ and SP2 measurements presented here, this 


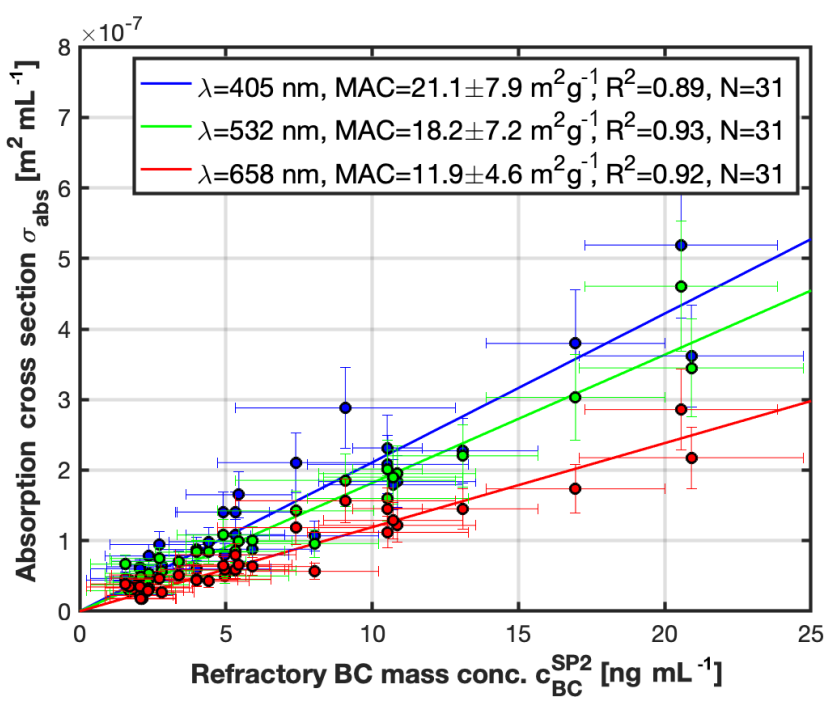

Figure 7. Snow mass-specific absorption cross section $\sigma_{\mathrm{abs}}$ of the snow samples (Eq. 1) as a function of the mass concentration $c_{\mathrm{BC}}^{\mathrm{SP} 2}$ deduced from the SP2 measurements. The BC mass-specific absorption cross section, MAC, is deduced from a linear regression without intercept of the data per wavelength and is given in the legend. See text for details.

quantity can be deduced in a similar way for the fresh snow samples from the UFS. For this purpose, the fullerene soot absorption-equivalent mass concentration $c_{\mathrm{BC}}^{\text {equiv }}$ was determined from the snow mass-specific absorption cross section $\sigma_{\mathrm{abs}}$ (Eq. 1) by applying the $\mathrm{MAC}_{\mathrm{FS}}$ determined for the fullerene soot suspensions (Sect. 4 and Fig. 3):

$c_{\mathrm{BC}}^{\text {equiv }}=\sigma_{\mathrm{abs}} / \mathrm{MAC} \mathrm{FS}$.

In Fig. 8, the deduced $c_{\mathrm{BC}}^{\text {equiv }}$ values for the 31 snow samples are plotted as a function of the $c_{\mathrm{BC}}^{\mathrm{SP} 2}$ mass concentrations. Interestingly, the two quantities are well correlated $\left(R^{2}\right.$ between 0.89 and 0.93 ) with mass "enhancement" factors (i.e. the correlation coefficients) $\gamma=\Delta c_{\mathrm{BC}}^{\text {equiv }} / \Delta c_{\mathrm{BC}}^{\mathrm{SP} 2}$ of 2.0 , 1.9 , and 1.4 for the 405,532 , and $658 \mathrm{~nm}$ wavelengths, respectively. This indicates that (i) there is a significant fraction of light absorption in the particle mass that cannot be attributed to refractory $\mathrm{BC}$, (ii) the reason for this additional absorption is correlated with the BC mass, and (iii) the additional absorption has a strong wavelength dependence between the blue and red part of the visible spectrum. To further elaborate on this observation, the snow mass-specific absorption cross section of the non-BC particles, $\sigma_{\mathrm{abs}}^{\text {nonBC }}$, was calculated from $\sigma_{\mathrm{abs}}$ of all particles:

$\sigma_{\mathrm{abs}}^{\mathrm{nonBC}}=\sigma_{\mathrm{abs}}-c_{\mathrm{BC}}^{\mathrm{SP} 2} \cdot \mathrm{MAC} \mathrm{FS} \times 10^{-9}$,

with $\mathrm{MAC}_{\mathrm{FS}}$ the mass absorption cross section of fullerene soot and a conversion factor of $10^{9} \mathrm{ng} \mathrm{g}^{-1}$. Figure 9 shows the statistical analysis of $\sigma_{\mathrm{abs}}^{\text {non }} \mathrm{BC}$ for the 31 snow samples

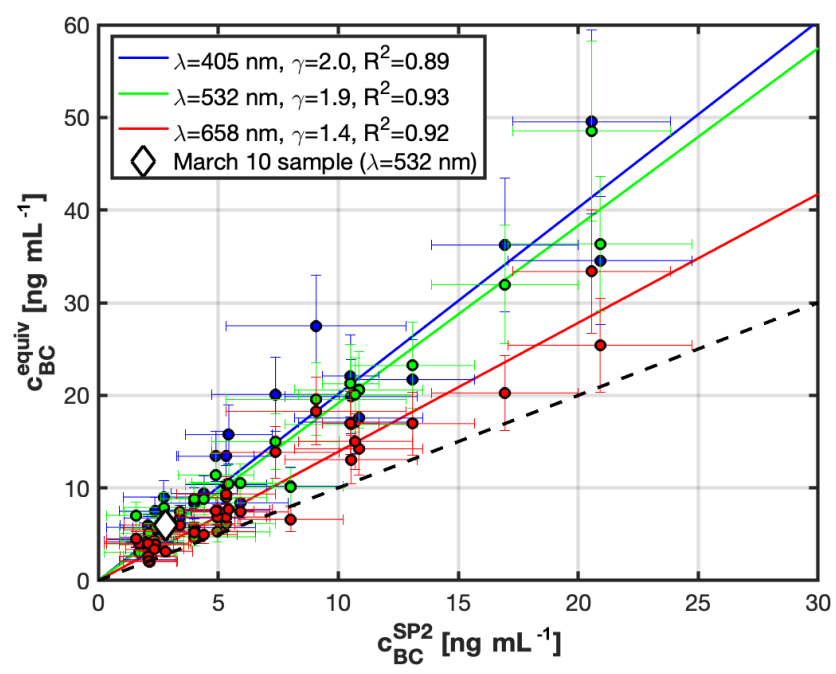

Figure 8. Equivalent $\mathrm{BC}$ mass concentration $c_{\mathrm{BC}}^{\text {equiv }}$, Eq. (2), of the snow samples as a function of the refractory BC mass concentration $c_{\mathrm{BC}}^{\mathrm{SP}}$. The dashed black line represents the $1: 1$ line. Linear regression without intercept per wavelength gives the mass "enhancement" factor $\lambda$, which is given in the legend. The white diamond symbol marks the $532 \mathrm{~nm}$ values of the 10 March snow sample that was further analysed for elemental composition, particle morphology, and fluorescence response. See text for details.

of the present study. Thus, the non-BC particles show an absorption characteristic with a gradual increase in $\sigma_{\text {abs }}^{\text {nonBC }}$ with decreasing wavelength, which is accompanied by a strong increase in its variability. Again, this points to co-deposited aerosol mass that predominantly absorbs in the blue and green part of the visible spectrum. As already mentioned, possible candidates for this additional light absorption are mineral dust and BrC.

Saharan dust events are routinely monitored by the DWD based on a combination of particle size distribution and calcium $\left(\mathrm{Ca}^{2+}\right)$ concentration measurements, which defines the Saharan Dust Index (SDI; Flentje et al., 2015). Based on the latest SDI inventory (https://www.dwd.de/EN/research/ observing_atmosphere/composition_atmosphere/aerosol/ cont_nav/saharan_dust.html, last access: 26 August 2019), the UFS station was influenced by Saharan dust on approximately $20 \mathrm{~d}$ within the period January to May 2017. Therefore, it is conclusive that Saharan dust likely influences the light absorption of the UFS snow samples. In an aerosol chamber study Wagner et al. (2012) deduced the complex refractive index, $m=n+i k$, of Saharan soil dust samples collected in a source region in southern Morocco during the SAMUM-1 field project (Heintzenberg, 2009). In Fig. 9, $\sigma_{\text {abs }}^{\text {nonBC }}$ is compared with the average spectrum of the imaginary part, $k$, of the refractive index deduced for the three Moroccan dust samples of the Wagner et al. (2012) study. Such a comparison is reasonable as the absorption cross section of mineral dust is dominated by the imaginary part of the refractive index (as well as the particle size 


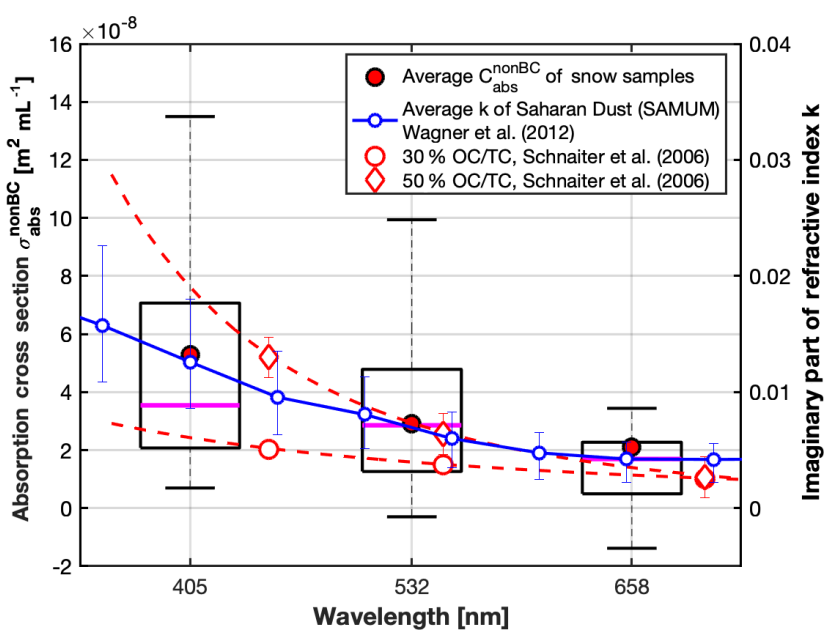

Figure 9. Statistical analysis of the snow mass-specific absorption cross section $\sigma_{\text {abs }}^{\text {non }}$ of the non-BC particles deduced from Eq. (3). Laboratory data of the imaginary part of refractive index, $k$, for Saharan dust (blue) and of the absorption cross section of brown carbon (red) are shown for comparison. Two examples of brown carbon $(\mathrm{BrC})$ with organic to total carbon mass ratio, OC/TC, of $30 \%$ and $50 \%$ are selected to emphasize the possible variability in spectral absorption of this class of atmospheric aerosol mass. A $\mathrm{BrC}$ in snow mass concentration of 4 and $18 \mathrm{ng} \mathrm{mL}^{-1}$ was assumed for the $30 \%$ and $50 \%$ example, respectively.

distribution) and less by the real part. While the Saharan dust spectrum closely resembles the spectral signature of $\sigma_{\mathrm{abs}}^{\text {nonBC }}$ with a very good match of the average values, the low spectral resolution and the high statistical variation of the $\sigma_{\text {abs }}^{\text {nonC }}$ data might also allow for a different interpretation. Schnaiter et al. (2006) used a propane diffusion flame to generate carbonaceous aerosol particles with different organic carbon (OC) mass fractions in the range from about $10 \%$ to $70 \%$. They found a strong correlation between the OC mass fraction and the wavelength dependence of the aerosol absorption with AAE between 1 and as large as 9 . Consequently, the particulate combustion emissions had different colours from black to brown to yellow, therefore representing brown carbon aerosol. Two examples from the Schnaiter et al. (2006) study are shown in Fig. 9 to highlight a possible contribution of $\mathrm{BrC}$ to the non-BC-absorbing aerosol mass in the snow samples. These two examples with OC mass fractions of $30 \%$ and $50 \%$ and mass-specific absorption cross sections of $3.8 \pm 0.5$ and $1.4 \pm 0.5 \mathrm{~m}^{2} \mathrm{~g}^{-1}$, respectively, are capable of covering the short-wavelength variation in $\sigma_{\text {abs }}^{\text {nonBC }}$ observed for the UFS snow samples. Here, reasonable mass concentrations of 4 and $18 \mathrm{ng} \mathrm{mL}^{-1}$ were assumed for the $30 \%$ and $50 \%$ OC samples, respectively, to calculate the snow mass-specific absorption cross section of $\mathrm{BrC}, \sigma_{\mathrm{abs}}^{\mathrm{BrC}}$, from the corresponding MAC that is given in Schnaiter et al. (2006). In summary, from a spectroscopic perspective the additional light-absorbing particle mass observed in the fresh UFS snow samples can be explained by long-range transported Saharan desert dust and/or $\mathrm{BrC}$ particles that are co-deposited in the snow together with the $\mathrm{BC}$ particles in varying compositions and mass concentrations.

As mentioned in Sect. 2.3, the snow sample from 10 March 2017 was further examined by supplementary measurement methods. The sample has a refractory $\mathrm{BC}$ mass concentration of $c_{\mathrm{BC}}^{\mathrm{SP} 2}=2.8 \mathrm{ng} \mathrm{mL}^{-1}$ and an equivalent $\mathrm{BC}$ mass concentration of $c_{\mathrm{BC}}^{\text {equiv }}=6.0 \mathrm{ng} \mathrm{mL}^{-1}$ for $\lambda=532 \mathrm{~nm}$, which gives a mass "enhancement" factor of $\gamma=2.1$. Therefore, the 10 March sample represents the bulk of the samples in terms of $\gamma$, but is on the lower side concerning $c_{\mathrm{BC}}^{\mathrm{SP} 2}$ and $c_{\mathrm{BC}}^{\text {equiv }}$ concentrations (see Fig. 8). The IC analysis of the snow sample, which was set to detect anions, shows only low concentrations of chloride, nitrate and sulfate of $0.29,1.1$ and $0.3 \mathrm{mg} \mathrm{L}^{-1}$, respectively. Only very low concentrations of alkaline and alkaline earth metals were found from the ICPMS analysis. For the trace metals manganese, iron, copper and zinc, concentrations of 9.7, 1.7, 1.1 and $8.7 \mu g \mathrm{~L}^{-1}$ were found, respectively.

The ESEM micrographs reveal that the larger $(>\sim 500 \mathrm{~nm})$ particles extracted from the 10 March snow sample predominantly consist of biogenic and biological materials including fragments of cellular membranes, whole bacteria, pollen, spores, and their mixtures. Mineral dust particles could be identified in the sample too, but to a much lesser extent than the biogenic particles. Figure S5 in the Supplement gives an overview composite image of a typical Nuclepore ${ }^{\mathrm{TM}}$ filter area, where particles with heavier elements like $\mathrm{Al}, \mathrm{Si}, \mathrm{Fe}, \mathrm{Mg}, \mathrm{K}$, and $\mathrm{Ti}$ are accentuated in green colour due to their brighter response in the backscatter electron detector (BSED). These elements are typically found in mineral dust particles, as compared to the lighter elements like $\mathrm{C}, \mathrm{N}, \mathrm{O}, \mathrm{Na}$, and $\mathrm{S}$ typical for biological material. This overview picture highlights the low relative abundance of mineral dust particles in the coarse mode particle size range of the sample. Representative examples of individual particles are given in Figs. 10 to 12. Note that the EDX spectra of all analysed particles are very characteristic for particle agglomerates or for chemical aging. The biogenic particle (Fig. 10) has areas showing intracellular composition (spot A) and pure cellular membrane fragments (spot B), whereas the mineral dust particle (Fig. 11) and soot particle (Fig. 12) exhibit spectra characteristics for both inorganic and biogenic material. Note that in contrast to the soot particle found in the snow sample (Fig. 12) the EDX spectrum of the fullerene soot particle does not contain any foreign chemical elements (Fig. 4).

The WIBS4 discriminates fluorescing biological aerosol particles (FBAPs) by combining single-particle fluorescence signals from two excitation-emission wavebands with a low cross-sensitivity to inorganic, combustion, and mineral dust particles (Toprak and Schnaiter, 2013). The WIBS4 measurement of the 10 March 2017 snow sample supports the 


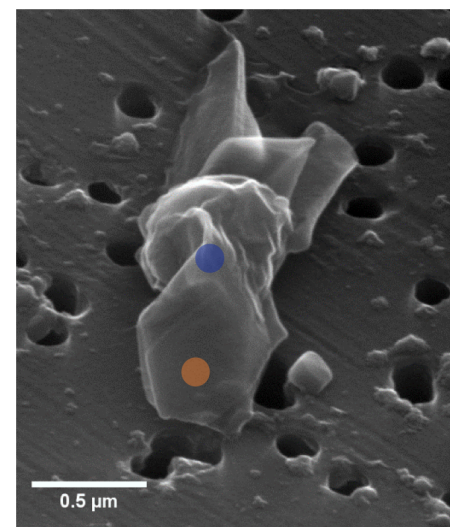

(a)

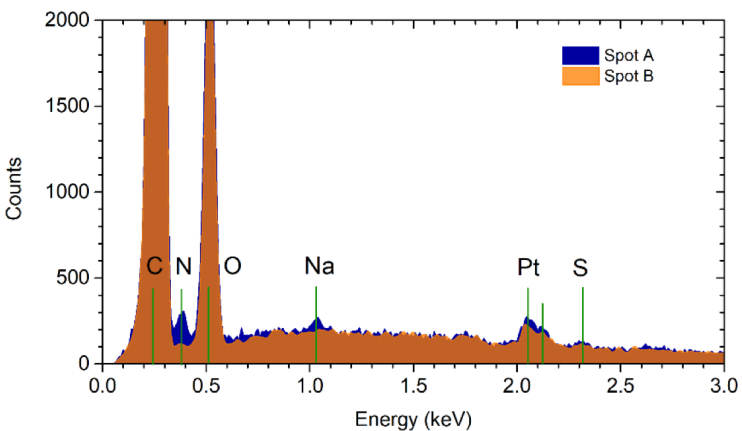

(b)

Figure 10. Same as Fig. 4 but for a biological particle. EDX spectra were obtained from different areas on the particle (marked as colour spots in the image). A clear biogenic signature (N, S, Na) is visible for the central bulky part, suggesting intracellular composition (spot A, blue colour), whereas the exterior part of the particle shows pure carbonaceous compounds $(\mathrm{C}, \mathrm{O})$ (spot $\mathrm{B}$, orange colour). Sample coating is responsible for the platinum peak.

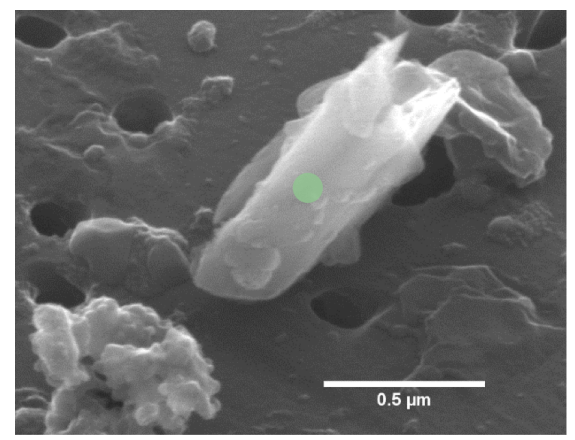

(a)

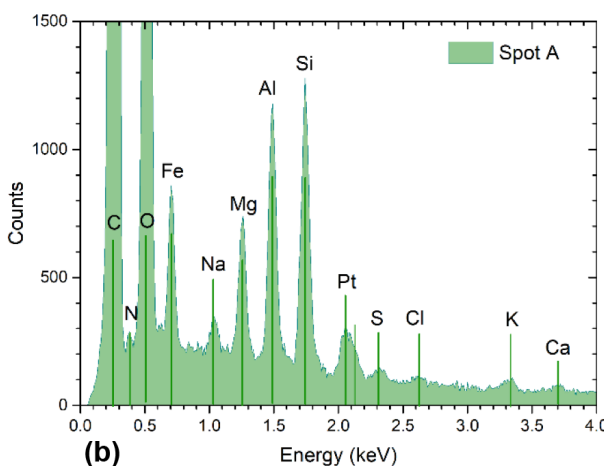

(b)

Figure 11. Same as Fig. 4 but for a mineral dust particle. The EDX spectrum of the particle identifies chemical patterns that are characteristic for mineral dust (Al, Si, Mg, Fe, K, Ca), biogenic ( $, \mathrm{Na}, \mathrm{Cl}, \mathrm{S})$, and carbonaceous (C, O) materials.

ESEM results of a high fraction of biogenic particles (43\%) in the size range larger than $0.5 \mu \mathrm{m}$ (see Fig. S6). The sizesegregated analysis reveals biogenic particle fractions of $80 \%$ and $100 \%$ for sizes larger than 2 and $3 \mu \mathrm{m}$, respectively.

While these results provide details of the physical and chemical nature of the particles that might contribute to the light absorption in the 10 March snow sample, they cannot be used to draw conclusions for all snow samples. Here, further analyses are required that could not be conducted within the scope of this pilot study. However, one question that arises from the above findings is whether the biogenic particles found in the 10 March snow sample can be attributed to $\mathrm{BrC}$, which was shown to be a good candidate for explaining the additional light absorption in the snow samples (Fig. 9). The term "brown carbon" is mainly related to a strong wavelength dependence of the visible light absorption observed in these materials. From a chemical perspective, $\mathrm{BrC}$ can generally be divided into humic-like substances (HULIS) and tar balls (Wu et al., 2016). HULIS can be characterized mainly as a mixture of macromolecular organic compounds with various functional groups and are expected in oxidation processes of biogenic precursors (Wu et al., 2016). Tar balls are emitted from biomass burning and are of spherical, amorphous structure and are typically not aggregated. Moreover, light-absorbing organic material and HULIS can be formed from the water-soluble fraction of biomass burning aerosol compounds, and are therefore suggested as an atmospheric process for the formation of light-absorbing $\mathrm{BrC}$ in cloud droplets (Hoffer et al., 2004). Further examination of snow samples from different locations as well as systematic investigations on the optical behaviour of biogenic particulate matter are therefore necessary to evaluate the influence of biogenic (including biological), $\mathrm{BrC}$ and mineral dust on the aerosol absorption properties in the visible spectral range. 


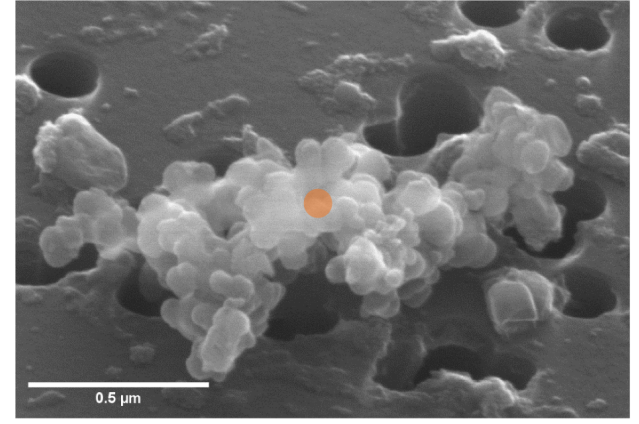

(a)

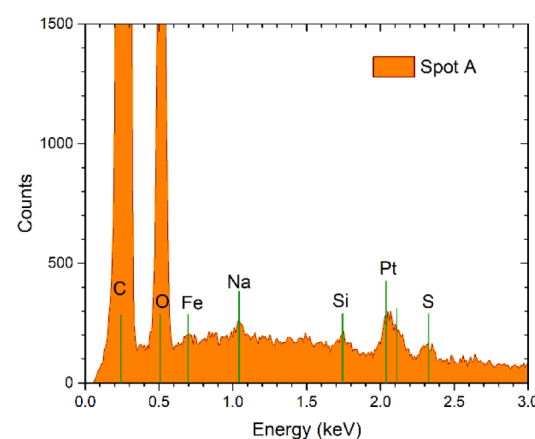

(b)

Figure 12. Same as Fig. 4 but for a soot (BC) particle. The EDX spectrum of the particle reveals trace elements of Fe, Na, Si, and $\mathrm{S}$ in addition to the dominating $\mathrm{C}, \mathrm{O}$ pattern that is characteristic for carbonaceous matter.

\section{Conclusions}

In this study a new laboratory analysis method for snow and ice samples was presented. With this method the snow massspecific absorption cross section $\sigma_{\text {abs }}$ is directly measured by the three-wavelength photoacoustic absorption spectrometer PAAS- $3 \lambda$ on re-aerosolized snow samples without particle deposition on filters. The refractory black carbon (BC) mass concentration in the snow samples was concurrently determined using a Single Particle Soot Photometer (SP2). Using water suspensions of fullerene soot particles of known BC mass concentrations as a BC reference for the snow samples, the aerosolization efficiency of the nebulizer was quantified and the detection limit of the method was assessed. Further, the mass-specific absorption cross section of fullerene soot $\left(\mathrm{MAC}_{\mathrm{FS}}\right)$ was determined for the visible spectral range from the concurrent PAAS-3 $\lambda$ and SP2 measurements.

The method was used to analyse 31 fresh snow samples collected at the Environmental Research Station Schneefernerhaus (UFS) in the winter of 2016/2017. The spectral snow mass-specific absorption cross sections $\sigma_{\text {abs }}$ measured by the PAAS- $3 \lambda$ were analysed as a function of the refractory BC snow mass mixing ratio $c_{\mathrm{BC}}^{\mathrm{SP} 2}$ deduced by the SP2 to determine the BC mass-specific absorption cross section (MAC) and the equivalent $\mathrm{BC}$ mass mixing ratio $c_{\mathrm{BC}}^{\text {equiv }}$ of the snow samples. Contrasting the MAC of the snow samples with the $\mathrm{MAC}_{\mathrm{FS}}$ of the fullerene soot reference $\mathrm{BC}$ material, it was found that the MAC of the snow particles was enhanced by a factor of 2 in the blue and green part of the visible spectrum, resulting in an enhanced $c_{\mathrm{BC}}^{\text {equiv }}$ mass mixing ratio compared to $c_{\mathrm{BC}}^{\mathrm{SP} 2}$. While the latter accounts only for the refractory $\mathrm{BC}$, it was concluded that the discrepancy between the optically deduced $c_{\mathrm{BC}}^{\text {equiv }}$ and the $c_{\mathrm{BC}}^{\mathrm{SP} 2}$ suggests the presence of light-absorbing non-BC particles in the snow samples. The good correlation between $c_{\mathrm{BC}}^{\text {equiv }}$ and $c_{\mathrm{BC}}^{\mathrm{SP} 2}$ further indicates that the non- $\mathrm{BC}$ and $\mathrm{BC}$ aerosol particles have either the same source (e.g. biomass burning) or experienced significant atmospheric processing (e.g. internal mixing) before they were deposited into the snow. Using the $\mathrm{MAC}_{\mathrm{FS}}$ of fullerene soot and the $c_{\mathrm{BC}}^{\mathrm{SP} 2}$ mass mixing ratio measured for the snow samples, the snow mass-specific absorption cross section $\sigma_{\mathrm{abs}}^{\text {nonBC }}$ of the non-BC particles could be determined. The spectral behaviour of $\sigma_{\mathrm{abs}}^{\text {nonBC }}$ gives mean absorption Angström exponents of 2.2 and 1.5 for the 405 to 532 and 532 to $658 \mathrm{~nm}$ spectral ranges, respectively, indicating that the non-BC light-absorbing particle mass is predominantly absorbing in the blue to green part of the visible spectrum and less in the red. By comparing $\sigma_{\mathrm{abs}}^{\text {nonBC }}$ with laboratory data for Saharan dust and organic (brown) carbon, it could be shown that these atmospheric aerosol components can explain the observed non-BC light absorption in the snow. Additional analyses of an exemplary snow sample using environmental scanning electron microscopy combined with EDX microanalysis as well as single-particle fluorescence measurements revealed that the larger particles of the snow sample are predominantly of biogenic or organic origin with lower contributions from mineral dust. This finding supports the above interpretation that the additional non-BC light absorbing aerosol mass is likely due to biogenic particles, brown carbon and mineral dust. Further studies are required that include samples from other locations, to quantify the general contribution of these non-BC atmospheric aerosol components to the visible light absorption in snow and ice surfaces and the resulting albedo reduction.

Data availability. All data presented in this paper are available upon request from the corresponding author (martin.schnaiter@kit.edu).

Supplement. The supplement related to this article is available online at: https://doi.org/10.5194/acp-19-10829-2019-supplement.

Author contributions. TR and FW collected, stored and transported the snow samples. CL, II and FW set up and characterized the instrumentation and conducted the snow sample optical and BC mass measurements. AK and CL analysed the 10 March 2017 sample 
with SEM, EDX and WIBS4. SN conducted the IC and the ICP-MS analyses. MS analysed the data and wrote the manuscript with the help of CL. TL was involved in the interpretation of the data. All commented on the manuscript.

Competing interests. The authors declare that they have no conflict of interest.

Acknowledgements. We thank Ludwig Ries, German Federal Environment Agency (UBA), and Gerhard Müller, German Meteorological Service (DWD), Global Observatory Zugspitze/Hohenpeissenberg, for providing weather, atmospheric BC and Saharan dust inventory data. Joshua Schwarz, National Oceanic and Atmospheric Administration (NOAA), Boulder, USA, is thanked for providing snow sample data for comparison. Shawn Wagner and Henno Havenga are thanked for native-speaker proofreading. This work was funded within the Helmholtz Research Program Atmosphere and Climate.

Financial support. The article processing charges for this openaccess publication were covered by a Research Centre of the Helmholtz Association.

Review statement. This paper was edited by Paul Zieger and reviewed by three anonymous referees.

\section{References}

Baumgardner, D., Popovicheva, O., Allan, J., Bernardoni, V., Cao, J., Cavalli, F., Cozic, J., Diapouli, E., Eleftheriadis, K., Genberg, P. J., Gonzalez, C., Gysel, M., John, A., Kirchstetter, T. W., Kuhlbusch, T. A. J., Laborde, M., Lack, D., Müller, T., Niessner, R., Petzold, A., Piazzalunga, A., Putaud, J. P., Schwarz, J., Sheridan, P., Subramanian, R., Swietlicki, E., Valli, G., Vecchi, R., and Viana, M.: Soot reference materials for instrument calibration and intercomparisons: a workshop summary with recommendations, Atmos. Meas. Tech., 5, 1869-1887, https://doi.org/10.5194/amt-5-1869-2012, 2012.

Birmili, W., Göbel, T., Sonntag, A., Ries, L., Sohmer, R., Gilge, S., Levin, I., and Stohl, A.: A case of transatlantic aerosol transport detected at the Schneefernerhaus observatory $(2650 \mathrm{~m})$ on the northern edge of the Alps, Meteorol. Zeitschrift, 19, 591600, https://doi.org/10.1127/0941-2948/2010/0465, 2010.

Bond, T. C., Doherty, S. J., Fahey, D. W., Forster, P. M., Berntsen, T., Deangelo, B. J., Flanner, M. G., Ghan, S., Kärcher, B., Koch, D., Kinne, S., Kondo, Y., Quinn, P. K., Sarofim, M. C., Schultz, M. G., Schulz, M., Venkataraman, C., Zhang, H., Zhang, S., Bellouin, N., Guttikunda, S. K., Hopke, P. K., Jacobson, M. Z., Kaiser, J. W., Klimont, Z., Lohmann, U., Schwarz, J. P., Shindell, D., Storelvmo, T., Warren, S. G., and Zender, C. S.: Bounding the role of black carbon in the climate system: A scientific assessment, J. Geophys. Res.-Atmos., 118, 5380-5552, https://doi.org/10.1002/jgrd.50171, 2013.
Boucher, O., Randall, D., Artaxo, P., Bretherton, C., Feingold, G., Forster, P., Kerminen, V.-M. V.-M., Kondo, Y., Liao, H., Lohmann, U., Rasch, P., Satheesh, S. K., Sherwood, S., Stevens, B., Zhang, X. Y., and Zhan, X. Y.: Clouds and Aerosols, Clim. Chang. 2013 Phys. Sci. Basis. Contrib. Work. Gr. I to Fifth Assess. Rep. Intergov. Panel Clim. Chang., 571-657, https://doi.org/10.1017/CBO9781107415324.016, 2013.

Clarke, A. D. and Noone, K. J.: Soot in the Arctic snowpack: a cause for perturbations in radiative transfer, Atmos. Environ., 19, 2045-2053, https://doi.org/10.1016/0004-6981(85)90113-1, 1985.

Dal Farra, A., Kaspari, S., Beach, J., Bucheli, T. D., Schaepman, M., and Schwikowski, M.: Spectral signatures of submicron scale light-absorbing impurities in snow and ice using hyperspectral microscopy, J. Glaciol., 64, 377-386, https://doi.org/10.1017/jog.2018.29, 2018.

Doherty, S. J., Warren, S. G., Grenfell, T. C., Clarke, A. D., and Brandt, R. E.: Light-absorbing impurities in Arctic snow, Atmos. Chem. Phys., 10, 11647-11680, https://doi.org/10.5194/acp-1011647-2010, 2010.

Dong, Z., Kang, S., Qin, D., Shao, Y., Ulbrich, S., and Qin, $\mathrm{X}$.: Variability in individual particle structure and mixing states between the glacier-snowpack and atmosphere in the northeastern Tibetan Plateau, The Cryosphere, 12, 3877-3890, https://doi.org/10.5194/tc-12-3877-2018, 2018.

Fischer, D. A. and Smith, G. D.: A portable, four-wavelength, single-cell photoacoustic spectrometer for ambient aerosol absorption, Aerosol Sci. Technol., 52, 393-406, https://doi.org/10.1080/02786826.2017.1413231, 2018.

Flanner, M. G., Zender, C. S., Randerson, J. T., and Rasch, P. J.: Present-day climate forcing and response from black carbon in snow, J. Geophys. Res.-Atmos., 112, 1-17, https://doi.org/10.1029/2006JD008003, 2007.

Flentje, H., Briel, B., Beck, C., Collaud Coen, M., Fricke, M., Cyrys, J., Gu, J., Pitz, M., and Thomas, W.: Identification and monitoring of Saharan dust: An inventory representative for south Germany since 1997, Atmos. Environ., 109, 87-96, https://doi.org/10.1016/j.atmosenv.2015.02.023, 2015.

Gilge, S., Plass-Duelmer, C., Fricke, W., Kaiser, A., Ries, L., Buchmann, B., and Steinbacher, M.: Ozone, carbon monoxide and nitrogen oxides time series at four alpine GAW mountain stations in central Europe, Atmos. Chem. Phys., 10, 12295-12316, https://doi.org/10.5194/acp-10-12295-2010, 2010.

Gorelik, O. P., Dyuzhev, G. A., Novikov, D. V., Oichenko, V. M., and Fursei, G. N.: Cluster structure of fullerene-containing soot and $\mathrm{C}_{60}$ fullerene powder, Tech. Phys., 45, 1489-1495, https://doi.org/10.1134/1.1325035, 2002.

Grenfell, T. C., Doherty, S. J., Clarke, A. D., and Warren, S. G.: Light absorption from particulate impurities in snow and ice determined by spectrophotometric analysis of filters, Appl. Optics, 50, 2037, https://doi.org/10.1364/ao.50.002037, 2011.

Gysel, M., Laborde, M., Olfert, J. S., Subramanian, R., and Gröhn, A. J.: Effective density of Aquadag and fullerene soot black carbon reference materials used for SP2 calibration, Atmos. Meas. Tech., 4, 2851-2858, https://doi.org/10.5194/amt-4-2851-2011, 2011.

Heintzenberg, J.: The SAMUM-1 experiment over Southern Morocco: Overview and introduction, Tellus, B, 61, 2-11, https://doi.org/10.1111/j.1600-0889.2008.00403.x, 2009. 
Hoffer, A., Kiss, G., Blazsó, M., and Gelencsér, A.: Chemical characterization of humic-like substances (HULIS) formed from a lignin-type precursor in model cloud water, Geophys. Res. Lett., 31, L06115, https://doi.org/10.1029/2003g1018962, 2004.

Kahnert, M., Nousiainen, T., Lindqvist, H., and Ebert, M.: Optical properties of light absorbing carbon aggregates mixed with sulfate: assessment of different model geometries for climate forcing calculations, Opt. Express, 20, 10042, https://doi.org/10.1364/oe.20.010042, 2012.

Kaspari, S., Painter, T. H., Gysel, M., Skiles, S. M., and Schwikowski, M.: Seasonal and elevational variations of black carbon and dust in snow and ice in the Solu-Khumbu, Nepal and estimated radiative forcings, Atmos. Chem. Phys., 14, 80898103, https://doi.org/10.5194/acp-14-8089-2014, 2014.

Kaspari, S. D., Schwikowski, M., Gysel, M., Flanner, M. G., Kang, S., Hou, S., and Mayewski, P. A.: Recent increase in black carbon concentrations from a Mt. Everest ice core spanning 1860-2000 AD, Geophys. Res. Lett., 38, L04703, https://doi.org/10.1029/2010GL046096, 2011.

Katich, J. M., Perring, A. E., and Schwarz, J. P.: Optimized detection of particulates from liquid samples in the aerosol phase: Focus on black carbon, Aerosol Sci. Technol., 51, 543-553, https://doi.org/10.1080/02786826.2017.1280597, 2017.

Kondo, Y., Sahu, L., Moteki, N., Khan, F., Takegawa, N., Liu, X., Koike, M., and Miyakawa, T.: Consistency and traceability of black carbon measurements made by laser-induced incandescence, thermal-optical transmittance, and filter-based photoabsorption techniques, Aerosol Sci. Technol., 45, 295-312, https://doi.org/10.1080/02786826.2010.533215, 2011.

Laborde, M., Mertes, P., Zieger, P., Dommen, J., Baltensperger, U., and Gysel, M.: Sensitivity of the Single Particle Soot Photometer to different black carbon types, Atmos. Meas. Tech., 5, 10311043, https://doi.org/10.5194/amt-5-1031-2012, 2012a.

Laborde, M., Schnaiter, M., Linke, C., Saathoff, H., Naumann, K.H., Möhler, O., Berlenz, S., Wagner, U., Taylor, J. W., Liu, D., Flynn, M., Allan, J. D., Coe, H., Heimerl, K., Dahlkötter, F., Weinzierl, B., Wollny, A. G., Zanatta, M., Cozic, J., Laj, P., Hitzenberger, R., Schwarz, J. P., and Gysel, M.: Single Particle Soot Photometer intercomparison at the AIDA chamber, Atmos. Meas. Tech., 5, 3077-3097, https://doi.org/10.5194/amt-5-30772012, 2012b.

Langridge, J. M., Richardson, M. S., Lack, D. A., Brock, C. A., and Murphy, D. M.: Limitations of the Photoacoustic Technique for Aerosol Absorption Measurement at High Relative Humidity, Aerosol Sci. Technol., 47, 1163-1173, https://doi.org/10.1080/02786826.2013.827324, 2013.

Linke, C., Ibrahim, I., Schleicher, N., Hitzenberger, R., Andreae, M. O., Leisner, T., and Schnaiter, M.: A novel singlecavity three-wavelength photoacoustic spectrometer for atmospheric aerosol research, Atmos. Meas. Tech., 9, 5331-5346, https://doi.org/10.5194/amt-9-5331-2016, 2016.

Liu, C., Xu, X., Yin, Y., Schnaiter, M., and Yung, Y. L.: Black carbon aggregates: A database for optical properties, J. Quant. Spectrosc. Ra., 222-223, 170-179, https://doi.org/10.1016/j.jqsrt.2018.10.021, 2019.

Moosmüller, H., Chakrabarty, R. K., and Arnott, W. P.: Aerosol light absorption and its measurement: A review, J. Quant. Spectrosc. Ra., 110, 844-878, https://doi.org/10.1016/j.jqsrt.2009.02.035, 2009.
Schmale, J., Flanner, M., Kang, S., Sprenger, M., Zhang, Q., Guo, J., Li, Y., Schwikowski, M., and Farinotti, D.: Modulation of snow reflectance and snowmelt from Central Asian glaciers by anthropogenic black carbon, Sci. Rep.-UK, 7, 1-10, https://doi.org/10.1038/srep40501, 2017.

Schnaiter, M., Linke, C., Möhler, O., Naumann, K. H., Saathoff, H., Wagner, R., Schurath, U., and Wehner, B.: Absorption amplification of black carbon internally mixed with secondary organic aerosol, J. Geophys. Res., 110, D19204, https://doi.org/10.1029/2005JD006046, 2005.

Schnaiter, M., Gimmler, M., Llamas, I., Linke, C., Jäger, C., and Mutschke, H.: Strong spectral dependence of light absorption by organic carbon particles formed by propane combustion, Atmos. Chem. Phys., 6, 2981-2990, https://doi.org/10.5194/acp-6-29812006, 2006.

Schwarz, J. P., Doherty, S. J., Li, F., Ruggiero, S. T., Tanner, C. E., Perring, A. E., Gao, R. S., and Fahey, D. W.: Assessing Single Particle Soot Photometer and Integrating Sphere/Integrating Sandwich Spectrophotometer measurement techniques for quantifying black carbon concentration in snow, Atmos. Meas. Tech., 5, 2581-2592, https://doi.org/10.5194/amt-5-2581-2012, 2012.

Schwarz, J. P., Gao, R. S., Perring, A. E., Spackman, J. R., and Fahey, D. W.: Black carbon aerosol size in snow., Nat. Sci. Rep., 3, 1356, https://doi.org/10.1038/srep01356, 2013.

Sinha, P. R., Kondo, Y., Goto-Azuma, K., Tsukagawa, Y., Fukuda, K., Koike, M., Ohata, S., Moteki, N., Mori, T., Oshima, N., Førland, E. J., Irwin, M., Gallet, J. C., and Pedersen, C. A.: Seasonal Progression of the Deposition of Black Carbon by Snowfall at Ny-Ålesund, Spitsbergen, J. Geophys. Res.-Atmos., 123, 9971016, https://doi.org/10.1002/2017JD028027, 2018.

Sun, J., Birmili, W., Hermann, M., Tuch, T., Weinhold, K., Spindler, G., Schladitz, A., Bastian, S., Löschau, G., Cyrys, J., Gu, J., Flentje, H., Briel, B., Asbach, C., Kaminski, H., Ries, L., Sohmer, R., Gerwig, H., Wirtz, K., Meinhardt, F., Schwerin, A., Bath, O., Ma, N., and Wiedensohler, A.: Variability of black carbon mass concentrations, sub-micrometer particle number concentrations and size distributions: results of the German Ultrafine Aerosol Network ranging from city street to High Alpine locations, Atmos. Environ., 202, 256-268, https://doi.org/10.1016/j.atmosenv.2018.12.029, 2019.

Teng, S., Liu, C., Schnaiter, M., Chakrabarty, R. K., and Liu, F.: Accounting for the effects of nonideal minor structures on the optical properties of black carbon aerosols, Atmos. Chem. Phys., 19, 2917-2931, https://doi.org/10.5194/acp-19-2917-2019, 2019.

Toprak, E. and Schnaiter, M.: Fluorescent biological aerosol particles measured with the Waveband Integrated Bioaerosol Sensor WIBS-4: laboratory tests combined with a one year field study, Atmos. Chem. Phys., 13, 225-243, https://doi.org/10.5194/acp13-225-2013, 2013.

Wagner, R., Ajtai, T., Kandler, K., Lieke, K., Linke, C., Müller, T., Schnaiter, M., and Vragel, M.: Complex refractive indices of Saharan dust samples at visible and near UV wavelengths: a laboratory study, Atmos. Chem. Phys., 12, 2491-2512, https://doi.org/10.5194/acp-12-2491-2012, 2012.

Warren, G. S.: Optical properties of snow, Rev. Geophys. Space Phys., 20, 67-89, 1982.

Warren, S. G.: Light-Absorbing Impurities in Snow: A Personal and Historical Account, Front. Earth Sci., 6, 1-8, https://doi.org/10.3389/feart.2018.00250, 2019. 
Warren, S. G. and Wiscombe, W. J.: A Model for the Spectral Albedo of Snow. II: Snow Containing Atmospheric Aerosols, J. Atmos. Sci., 37, 2734-2745, 1980.

Warren, S. G. and Wiscombe, W. J.: Dirty snow after nuclear war, Nature, 313, 467-470, https://doi.org/10.1038/313467a0, 1985.

Wendl, I. A., Menking, J. A., Färber, R., Gysel, M., Kaspari, S. D., Laborde, M. J. G., and Schwikowski, M.: Optimized method for black carbon analysis in ice and snow using the Single Particle Soot Photometer, Atmos. Meas. Tech., 7, 2667-2681, https://doi.org/10.5194/amt-7-2667-2014, 2014.

Wu, G. M., Cong, Z. Y., Kang, S. C., Kawamura, K., Fu, P. Q., Zhang, Y. L., Wan, X., Gao, S. P., and Liu, B.: Brown carbon in the cryosphere: Current knowledge and perspective, Adv. Clim. Chang. Res., 7, 82-89, https://doi.org/10.1016/j.accre.2016.06.002, 2016.

You, R., Radney, J. G., Zachariah, M. R., and Zangmeister, C. D.: Measured Wavelength-Dependent Absorption Enhancement of Internally Mixed Black Carbon with Absorbing and Nonabsorbing Materials, Environ. Sci. Technol., 50, 7982-7990, https://doi.org/10.1021/acs.est.6b01473, 2016.

Yuan, Y., Ries, L., Petermeier, H., Trickl, T., Leuchner, M., Couret, C., Sohmer, R., Meinhardt, F., and Menzel, A.: On the diurnal, weekly, and seasonal cycles and annual trends in atmospheric $\mathrm{CO}_{2}$ at Mount Zugspitze, Germany, during 1981-2016, Atmos. Chem. Phys., 19, 999-1012, https://doi.org/10.5194/acp-19-9992019, 2019.
Zangmeister, C. D., You, R., Lunny, E. M., Jacobson, A. E., Okumura, M., Zachariah, M. R., and Radney, J. G.: Measured in-situ mass absorption spectra for nine forms of highlyabsorbing carbonaceous aerosol, Carbon N. Y., 136, 85-93, https://doi.org/10.1016/j.carbon.2018.04.057, 2018.

Zhang, Y., Kang, S., Li, C., Gao, T., Cong, Z., Sprenger, M., Liu, Y., Li, X., Guo, J., Sillanpää, M., Wang, K., Chen, J., Li, Y., and Sun, S.: Characteristics of black carbon in snow from Laohugou No. 12 glacier on the northern Tibetan Plateau, Sci. Total Environ., 607-608, 1237-1249, https://doi.org/10.1016/j.scitotenv.2017.07.100, 2017.

Zhang, Y., Kang, S., Sprenger, M., Cong, Z., Gao, T., Li, C., Tao, S., Li, X., Zhong, X., Xu, M., Meng, W., Neupane, B., Qin, X., and Sillanpää, M.: Black carbon and mineral dust in snow cover on the Tibetan Plateau, The Cryosphere, 12, 413-431, https://doi.org/10.5194/tc-12-413-2018, 2018.

Zhou, Y., Wang, X., Wu, X., Cong, Z., Wu, G., and Ji, M.: Quantifying light absorption of iron oxides and carbonaceous aerosol in seasonal snow across Northern China, Atmosphere (Basel), 8, 15-22, https://doi.org/10.3390/atmos8040063, 2017. 